Golden Gate University School of Law GGU Law Digital Commons

2009

Our Bandit Future - Cities, Shantytowns, and Climate Change Governance

Colin Crawford

Follow this and additional works at: https://digitalcommons.law.ggu.edu/pubs

Part of the Environmental Law Commons, and the Land Use Law Commons 


\section{HEINONLINE}

DATE DOWNLOADED: Mon Mar 29 18:43:44 2021

SOURCE: Content Downloaded from HeinOnline

Citations:

Bluebook 21st ed.

Colin Crawford, Our Bandit Future - Cities, Shantytowns, and Climate Change Governance, 36 FORDHAM URB. L.J. 211 (2009).

ALWD 6th ed.

Crawford, C. ., Our bandit future - cities, shantytowns, and climate change governance, 36(2) Fordham Urb. L.J. 211 (2009).

APA 7th ed.

Crawford, C. (2009). Our bandit future cities, shantytowns, and climate change governance. Fordham Urban Law Journal, 36(2), 211-252.

Chicago 17th ed.

Colin Crawford, "Our Bandit Future - Cities, Shantytowns, and Climate Change Governance," Fordham Urban Law Journal 36, no. 2 (February 2009): 211-252

McGill Guide 9th ed.

Colin Crawford, "Our Bandit Future - Cities, Shantytowns, and Climate Change

Governance" (2009) 36:2 Fordham Urb LJ 211.

AGLC 4th ed.

Colin Crawford, 'Our Bandit Future - Cities, Shantytowns, and Climate Change Governance' (2009) 36(2) Fordham Urban Law Journal 211.

MLA 8th ed.

Crawford, Colin. "Our Bandit Future - Cities, Shantytowns, and Climate Change

Governance." Fordham Urban Law Journal, vol. 36, no. 2, February 2009, p. 211-252.

HeinOnline.

OSCOLA 4th ed.

Colin Crawford, 'Our Bandit Future - Cities, Shantytowns, and Climate Change

Governance' (2009) 36 Fordham Urb LJ 211

Provided by:

Golden Gate University School of Law Library

-- Your use of this HeinOnline PDF indicates your acceptance of HeinOnline's Terms and Conditions of the license agreement available at https://heinonline.org/HOL/License

-- The search text of this PDF is generated from uncorrected OCR text.

-- To obtain permission to use this article beyond the scope of your license, please use: Copyright Information 


\title{
OUR BANDIT FUTURE? CITIES, SHANTYTOWNS, AND CLIMATE CHANGE GOVERNANCE
}

\author{
Colin Crawford
}

Introduction

I. Cities, Shantytowns, and Extra-Legal Settlements............................216

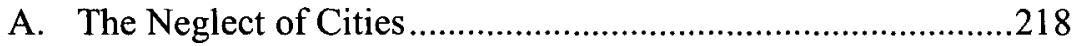

B. Defining Interests Within Cities ............................................221

II. Consequences of not Hearing from Cities in Climate Change

Debate

III. Refocusing the Climate Change Debate and Norm Articulation by City Voices

A. Who Is Heard in Climate Change Discussions.

B. Towards New Governance Norms: Some Benefits of

Listening to Cities and Shantytowns

1. Adding Unheard Voices

2. Proposals for Infrastructure and Land Reforms: Local Thinking to Aid Global Action

3. Focus on Environmental Justice in Climate Change Governance

IV. The Search for a Solution

A. The Example of Participatory Budgeting ..............................244

B. Promoting Citizen Participation in Distributive Justice

Decisions

C. Effectiveness of Decisions.

\footnotetext{
* Professor of Law and Co-Director, Center for the Comparative Study of Metropolitan Growth, Georgia State University College of Law. Jad Atallah, Georgia State Class of 2008 , and Robert Lafayette, Georgia State Class of 2009, provided exceptional research assistance in the preparation of this essay. Erik Bluemel provided useful criticisms and suggestions on an earlier draft. I am grateful to participants at the First Annual Cooper-Walsh Colloquium at Fordham University School of Law; to Professors Sheila Foster and Matthew Diller; to the Colloquium Editor, Frank Mitchell; and to the editor of this piece, Mark Sobel. The faculty of the University of Denver Sturm College of Law generously provided me with the opportunity to deliver an earlier version of this paper at a Faculty Development Workshop while I was a visitor at that institution. I remain responsible, of course, for any errors and shortcomings.
} 


\section{Participatory Democracy and the Accountability of Elected} Representatives.

\section{INTRODUCTION}

The effects of climate change on the world's cities and the people who live in them are not subjects that have received a great deal of attention, at least not in isolation from other climate change effects. Climate change effects tend to get considered in continental or regional terms: melting ice caps, agricultural crop losses across vast swaths of land, and shoreline loss that will inundate sub-continents. ${ }^{1}$ Alternately, the discussion tends to focus on behavioral change, again at the level of entire national populations, suggesting that countries must consider using cleaner energy sources, producing cleaner-burning vehicles, and providing incentives for citizens to insulate their homes better. ${ }^{2}$ Many, if not most, commentators seem to endorse the view that resolution of climate change challenges should be addressed at the global level and enforced by state parties pursuant to global accords. $^{3}$ More recently, there has been some discussion of the inequalities that climate change will exacerbate. Crudely put, the analysis posits that poorer nations, especially those in Asia and Africa, will become poorer,

1. See, e.g., David B. Lobell et al., Prioritizing Climate Change Adaptation Needs For Food Security in 2030, 319 SCIENCE 607, 607-10 (2008) (noting agricultural crop losses in Southern Africa and South Asia); Mark Stallworthy, Sustainability, Coastal Erosion and Climate Change: An Environmental Justice Analysis, 18 J. ENVTL. L. 357, 357-58 (2006) (noting shoreline loss on the Indian subcontinent, the Nile Delta, and islands in the Indian and Pacific Oceans); Deborah Zabarenko, Arctic Ice Cap Melting 30 Years Ahead of Forecast, REUTERS NEWS, May 1, 2007, http://www.reuters.com/article/scienceNews/idUSN01 22477020070501.

2. See, e.g., Daniel Roth, Driven: Shai Agassi's Audacious Plan to Put Electric Cars on the Road, WIRED, Aug. 18, 2008, at 118, 124-25 (discussing the collaboration between Project Better Place, Israel, and Renault-Nissan to build electric vehicles and use Israel as a test-bed for deployment); Choe Sang-Hun, South Korea Seeks Cleaner Energy New Solar and Tidal Power Plants Will Be World's Largest, INT'L HeRALD TRIB., May 10, 2007, at 11 (noting South Korea's aim to increase its use of renewable energy to $10 \%$ from the current $2.28 \%$ by 2020 ); Mass. Dep'T OF ENVTL. CONSERVATION, GREENHOUSE GaSES AND CliMATE CHANGE: WHAT CAN YOU Do?, http://www.mass.gov/dep/air/climate/ (last visited Oct. 18, 2008).

3. See, e.g., Jonathan H. Adler, Hothouse Flowers: The Vices and Virtues of Climate Federalism, 17 TEMP. POL. \& CrV. RTS. L. REV. 443 (2008); Elizabeth Burleson, Multilateral Climate Change Mitigation, 41 U.S.F. L. REv. 373 (2007); Jonathan B. Wiener, Think Globally, Act Globally: The Limits of Local Climate Policies, 155 U. PA. L. REV. 1961 (2007); Eric Posner \& Cass Sunstein, Should Greenhouse Gas Permits Be Allocated on a Per Capita Basis? 1 (U. Chi., Pub. Law Working Paper No. 206, 2008), available at http://ssm.com/ abstract=1105205 (beginning with the observation that "[m]any people believe that the problem of climate change would be best handled by an international agreement that includes a system of cap and trade."). See generally RICHARD STEWART \& JONATHAN WIENER, ReCONSTRUCTING Climate POlicy: BeyOND Kyoto (2003). 
while the richer nations will-if they do not become richer-suffer fewer of the negative consequences of climate change. ${ }^{4}$ In light of these differential climate change effects on poorer nations, some analysts have explored the probability of increased civil strife. However, even when the literature examines effects of climate change on civil strife, the analysis tends to address national roles and bilateral or multilateral national responses. ${ }^{5}$ Furthermore, when land use changes are discussed, urban land use is typically excluded from consideration. The focus tends to be on deforestation and agricultural land. ${ }^{6}$

This debate strikingly neglects what is arguably the dominant demographic shift of our era, namely the global trend towards urbanization-the move to mega-cities. As the United Nations Population Fund reports, in 2008, a majority of the world's population will live in urban areas. That number is expected to increase by another $50 \%$ by $2030 .^{7}$ In historical

4. See, e.g., Ruth Gordon, Climate Change and the Poorest Nations: Further Reflections on Global Inequality, 78 U. CoLO. L. REV. 1559, 1589-91 (2007) (indicating that global warming will have a disproportionate impact on low-income, unindustrialized nations); Amy Sinden, Climate Change and Human Rights, 27 J. LAND RESOURCES \& ENVTL. L. (forthcoming 2009), available at http://papers.ssrn.com/sol3/papers.cfm?abstract_id= 984266 (exploring application of human rights principles to guide climate change policy); Cass R. Sunstein, The World vs. the United States and China? The Complex Climate Change Incentives of the Leading Greenhouse Gas Emitters, 55 UCLA L. REV. 1675, 168283 (2008) (noting that poorer nations are likely to be the biggest losers due to climate change and the wealthier nations are less vulnerable and better able mitigate any negative consequences); R. Ramachandran, Burden of the Poor, FRONTLINE, Mar. 9, 2007, at 31, available at http://www.hinduonnet.com/fline/fl2404/stories/20070309003303100.htm (detailing an interview with $\mathrm{Dr}$. Saleemul Huq on the disproportionate impact of climate change on the poor and developing countries).

5. E.g., Elizabeth Burleson, Multilateral Climate Change Mitigation, 41 U.S.F. L. REV. 1 (2007) (noting multilateral options to address climate change); Sanford E. Gaines, Sustainable Development and National Security, 30 WM. \& MARY ENVTL. L. \& POL'Y ReV. 321,364 (2006) (discussing implications of greenhouse emissions and climate change on global security, particularly in causing floods, storms, and droughts in poor countries); Timothy L. Fort \& Cindy A. Schipani, Ecology and Violence: The Environmental Dimensions of War, 29 COLUM. J. ENVTL. L. 243 (2004) (analyzing the role of the environment and competition over limited resources in war). A notable exception is U.N. POPULATION FUND, State of World Population 2007: UNLEashing the Potential of URBan Growth 5859 (2007) [hereinafter STATE OF WORLD POPULATION]. Even then, however, the urban analysis constitutes one and a half pages in a 108-page report. The full report is available at http://www.unfpa.org/swp/2007/presskit/pdf/sowp2007_eng.pdf (last visited Feb. 6, 2009).

6. E.g., INTERgovernmental PaNel on Climate CHANGE, U.N. ENV'T PROgRaMme \& WORLd METEOROLOGICAL ORG., IPCC SPECIAL REPORT: LAND USE, LAND-USE ChANGE, AND FORESTRY SUMMARY FOR POLICYMAKERS (2000), available at http://www.ipcc.ch/ pdf/special-reports/spm/srl-en.pdf.

7. STATE OF WORld Population, supra note 5, at 1 ("For the first time in history, more than half its human population, 3.3 billion people, will be living in urban areas. By 2030 , this is expected to swell to almost 5 billion."). STATE OF WORLD POPULATION does not use a uniform definition for "urban areas" but explains that uses this term to refer to the 
terms, it is impossible to understate the significance of this phenomenon, especially inasmuch as the vast majority of these urban immigrants will arrive with few resources and live in slum conditions. ${ }^{8}$ Moreover, perhaps the characteristic feature of many such slums is that they are dominated by the informal economy, characterized by oppressive systems of patronage, corruption, and violence. ${ }^{9}$ As the world gets hotter, this seems likely to create a-perhaps literally-combustible situation. ${ }^{10}$ A host of factors, including environmental degradation, inadequate provision of environmental and infrastructure services, and limited employment opportunities are combining to turn many of the world's mega-slums into dangerous, violent places. ${ }^{\text {I }}$ Moreover, there is considerable literature that has examined the relationship between increased urban violence and temperature rise. ${ }^{12}$ It

definitions adopted by state statistical agencies, see STATE OF THE WORLD POPULATION, supra note 5, at 6; see also Daniel Howden, Planet of the Slums: UN Warns Urban Populations Set to Double, INDEPENDENT (U.K.), June 27, 2007 (writing about U.N. report finding that many new urbanites will be poor and live in slums).

8. STATE OF WORLd POPUlation, supra note 5, at 1 (" $[$ T] he next few decades will see an unprecedented scale of urban growth in the developing world. This will be particularly notable in Africa and Asia where the urban population will double between 2000 and 2030 . ... By 2030, the towns and cities of the developing world will make up 80 per cent of urban humanity."); see, e.g., Carlos Walter Porto-GonÇalves, A GlobalizaÇão da NatUREZa E a NATUREZa da GlobalizaÇão [Globalization of NATURE aND tHE NATURE OF GLOBALIZATION] 185-91 (2006) (reporting that $76 \%$ of the world's population live in slum conditions - 53 million of them, according to the U.N., in the "First World"-and that $83 \%$ of the world's urban population live in "precarious" conditions).

9. See, e.g., Mike Davis, Planet of Slums 185 (2006).

10. U.N. Framework Convention on Climate Change, essential Background: FEeling THe Heat, Summary For POliCYMAKers, http://unfecc.int/essential_background/ feeling_the_heat/items/2917.php (last visited Feb. 6, 2009) ("The average temperature of the earth's surface has risen by 0.74 degrees $C$ since the late $1800 \mathrm{~s}$. It is expected to increase by another $1.8^{\circ} \mathrm{C}$ to $4^{\circ} \mathrm{C}$ by the year $2100-$ a rapid and profound change-should the necessary action not be taken. Even if the minimum predicted increase takes place, it will be larger than any century-long trend in the last 10,000 years.").

11. A prominent researcher exploring the relationship between environmental scarcity, environmental crises, and violence is the Canadian social scientist Thomas Homer-Dixon. Although his work does not address climate change specifically, it does explore the relationship of environmental pressures and violence, including urban violence. See, e.g., THOMAS F. HOMER-DiXON, ENVIRONMENT, SCARCITY, AND VIOLENCE 155-68 (1999) (studying urban growth and violence); VAlerie Percival \& ThOMAS HomER-Dixon, The Case of South Africa, in ECO-VIOLENCE: LINKS AMONG ENVIRONMENT, POPUlation, AND SECURITY 109, 122-36 (Thomas Homer-Dixon \& Jessica Blitt eds., 1998) (studying the same for South African cities specifically).

12. See, e.g., Craig A. Anderson et al., Hot Temperatures, Hostile Affect, Hostile Cognition, and Arousal: Tests of a General Model of Affective Aggression, 21 PERsonaliTy \& SOC. PSYCHOL. BULL. 434, 434-48 (1995) (reporting results of two experiments examining hot temperature effects on aggression while playing video games and engaging in aerobic exercise; concluding that a direct relationship exists between hot temperatures and aggression); Craig A. Anderson et al., Hot Years and Serious Deadly Assault: Empirical Tests of 
does not seem unreasonable, therefore, to posit a connection between climate change and urban violence, one that calls for attention to the role of cities in resolving the adverse effects of climate change. This Article does not (because it cannot) presume to establish as an empirical matter that climate change is a cause of urban violence. Rather, the connection between urban violence and climate change provides the point of departure for this Article. That is, in light of the empirical work establishing a connection between urban violence and both environmental scarcity and temperature rise, this Article proceeds on the assumption that as an environmental pressure (perhaps the greatest environmental pressure), climate change can only exacerbate these phenomena.

In light of this connection and its serious social and economic consequences, this Article seeks, therefore, to begin to define a role for cities and their inhabitants in climate change governance. Part I argues that if we fail to take into account global urbanization and its defining characteristics, namely extreme squalor and associated social ills, as a central feature of climate change policy, we face, as a Rio de Janeiro taxi driver said to me during the hot, dry, violent winter of 2006 in that city, "um futuro bandido, "literally "a bandit future." That is, we face a future where cities, the places where most of the world's population lives, will experience sustained and perhaps intractable urban violence and social disintegration, a development that can only hasten the separate but related harms caused by

the Heat Hypothesis, 73 J. Personality \& Soc. Psychol. 1213 (1997) (reporting results of two studies looking at the relation between annual average temperature and crime rate in the years 1950-1995 and concluding that there is a direct link); Craig A. Anderson, Temperature and Aggression: The Ubiquitous Effects of Heat on Occurence of Human Violence, 106 PSYCHOL. BuLl. 74, 74 (1989) (reviewing relevant studies, violent crime, and domestic crime while taking into account geographic regions, seasons, and monthly variations; concluding that there is a direct link between heat and aggression); James Rotton \& Ellen G. Cohn, Global Warming and U.S. Crime Rates: An Application of Routine Activity Theory, 35 ENV'T \& BEHAV. 802 (2003) (finding that, for the period 1950-1999 in the United States, "annual temperatures were associated with assault but not murder rates in analyses that controlled for yearly population, ethnicity, and three economic variables"). But see, e.g., Michelle L. Bell et al., Vulnerability to Heat-Related Mortality in Latin America: A CaseCrossover Study in São Paulo, Brazil, Santiago, Chile and Mexico City, Mexico, 37 INT'L J. EPIDEMIOLOGY 796 (2008), available at http://ije.oxfordjournals.org/cgi/content/full/dyn094 (noting in passing the likelihood that climate change will exacerbate heat-related morbidity and mortality); Vania Ceccato, Homicide in São Paulo, Brazil: Assessing Spatial-temporal and Weather Variations, 25 J. ENV'T PSYCHOL. 307 (2005) (finding stronger homicidetemporal than homicide-climate correlation).

13. See Henry Chu, Rio Struggles to Contain Violence on the Eve of the Tourism Season, L.A. TImES, Nov. 26, 2004, at A3 (noting that "[w]ith every summer comes a spike in crimes against visitors" in Rio de Janeiro); Larry Rohter, 19 Are Killed as Drug Gangs Conduct Attacks in Brazil, N.Y. TiMES, Dec. 29, 2006, at A4 (reporting on the wave of violence in Rio de Janeiro that coincided with the start of the summer tourist season). 
climate change on the world's human and biological populations. Part I also explains that the term "cities" does not refer only-or even primarily-to elected or appointed municipal governments. Rather, Part I endorses an expansive understanding of cities to include both metropolitan areas on the official grid and also the shantytowns and slums, the expansive informal and extra-legal settlements that define urban living for millions the world over.

Part II explores some of the consequences of the inattention of the climate change literature, and especially the mainstream U.S.-based legal scholarship on climate change, to incorporate a voice for the world's megacities and their extensive mega-slums in climate change governance. In particular, Part II argues that the failure to incorporate a voice for cities reinforces existing and seemingly intractable divisions in international efforts to resolve climate change. Thus, elites with carbon-consumptive behaviors in "developing" countries can hide behind their nations' demands for reductions in "developed" countries, while, conversely, responsible actors in "developed" countries get grouped together with the carbon-consumptive habits of their economic betters. Part II therefore suggests that the presence of voices representing urban populations would help reveal some of the self-interest on all sides and redirect climate change law and policy towards the implementation of more equitable solutions.

Part III then outlines some of the normative advantages of city-inclusive governance in the context of climate change regulation. Part III thus suggests how incorporating voices from cities in climate change governance will serve the larger goals of climate change regulation, including emissions reductions strategies and particularly the goal of adaptive management.

Finally, Part IV outlines possible solutions to address the concerns addressed in the previous parts, suggesting ways in which climate change debate and the search for legal solutions to help combat the phenomenon might take account of global urbanization. Specifically, Part IV suggests ways in which a voice for cities, and in particular those urban residents usually without voices-in local or national, much less international forums - may be heard, and their views taken into account in reversing the negative effects of climate change.

\section{Cities, Shantytowns, AND ExTRA-Legal SeTtlements}

This Part seeks to establish the value of cities, or portions of them, as actors in the resolution of global climate change problems. First and most evidently, cities merit such a role because of their established strengths as 
centers of innovation and wealth. ${ }^{14}$ Cities are also, however, centers of inequality: it is this feature of modern cities that may be as important to addressing climate change as their more positive aspects, given that in reality poor urban areas are anticipated disproportionately to suffer the effects of global warming and associated ills. ${ }^{15}$ It may also be observed that city residents are especially concerned with climate change, in light of the dizzying profusion of local initiatives to address climate change. ${ }^{16}$ Yet, oddly,

14. Richard C. Schragger, Cities, Economic Development, and the Free Trade Constitution, 94 VA. L. REV. 1091, 1102-06 (2008) (acknowledging that cities are a key element of innovation and noting that urban areas generate the bulk of economic wealth in the United States).

15. See, e.g., INTERgovernmental PANEl ON Climate ChANGe, supra note 6.

16. Kevin Doran \& Alaine Ginnochio, United States Climate Policy: Using Market Based Strategies to Achieve Greenhouse Gas Emission Reductions, 3 ENVTL. \& ENERGY L. \& POL'Y J. 31, 52 (2008) (identifying "dizzying profusion" of local initiatives, assumed to occur because of a lack of federal action); David M. Driesen, The Changing Climate for United States Law, 1 CARBON \& Climate L. REV. 1, 36-41 (2007). A good summary of state-level programs is Pace Law Sch. Ctr. for Envtl. Legal Studies, The State Response to Climate Change: 50 State Survey, in MichaEl B. GeRRARD, Global Climate Change AND U.S. LAW 371 (2007), available at http://www.abanet.org/abapubs/globalclimate/docs/ stateupdate_1207.pdf. For examples of local climate change initiatives see California Global Warming Solutions Act of 2006, CAL. HEALTH \& SAFETY CODE $\S \S 38500-99$ (West 2008) (combining regulatory and marketplace mechanisms in an attempt to reduce the state's greenhouse gas emissions by $25 \%$ by 2020 ); City Council of Austin, Res. No. 20070215-023 (Tex. 2007), available at http://www.ci.austin.tx.us/acpp/downloads/acpp _res021507.pdf (resolving that climate change is a serious threat and creating a five-part plan, The Austin Climate Protection Plan, that seeks to reduce and reverse the negative impacts of global warming); GREATER LONDON AUTH., ACTION TODAY TO PROTECT TOMORRow: The Mayor's Climate Change ACtion Plan (2007), http://www.london.gov.uk/ mayor/environment/climate-change/docs/ccap_fullreport.pdf (noting London's plan to cut and maintain emissions at $60 \%$ below 1990 levels by 2025); S.F. DEP'T OF THE ENV'T \& S.F.

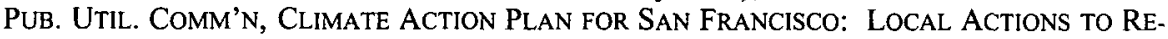
DUCE GREENHOUSE GAS EMISSIONS (2004), http://www.sfenvironment.org/downloads/ library/climateactionplan.pdf (noting San Francisco's plan to reduce overall greenhouse gas emissions to $20 \%$ below 1990 levels by 2012); MAYOR's GREENPRINT DENVER ADVISORY Council, City of Denver Climate ACtion Plan: Final ReCOMMENDations to Mayor HICKENLOOPER (2007), http://www,greenprintdenver.org/docs/DenverClimateActionPlan. pdf (outlining ten recommendations that are projected to achieve Denver's 2012 goal of reducing per capita greenhouse gas emissions by $10 \%$ below 1990 levels); CITY OF ASPEN CANARY INITIATIVE, ClimATE ACTION Plan 2007-2009 (2007), http://www.canaryinitiative. com/pdf/CAP.pdf (outlining Aspen's goals for addressing global warming and how they can be achieved; the Plan is also meant to act as a mechanism to monitor progress and as a guiding document for all policies developed within the City); CITY of L.A., GREEN LA: AN action Plan to Lead the Nation IN Fighting Global Warming (2007), http:// www.lacity.org/ead/EADWeb-AQD/GreenLA_CAP_2007.pdf (laying out Los Angeles's plan to reduce $\mathrm{CO}_{2}$ emissions $35 \%$ below 1990 levels by 2030); U.S. CONFERENCE OF MAYORS, The U.S. MAYORS Climate PRotection AGReEMENT (2005), http://www.usmayors. org/climateprotection/documents/mcpAgreement.pdf (describing a voluntary agreement signed by over 880 U.S. mayors in which participating cities agree to take the following actions: meet or beat the Kyoto Protocol targets in their own communities; urge their state 
in the United States, the federal government appears to object to this phenomenon; attempts are underway to silence local efforts to respond to climate change, even in the face of federal inaction. ${ }^{17}$

\section{A. The Neglect of Cities}

The neglect of cities in international climate change debates and, in particular, in U.S. legal scholarship addressing climate change is not entirely surprising. As Gerald Frug noted in a classic piece nearly three decades ago, cities have largely been rendered powerless in U.S. legal discourse and practice. Frug noted the paradox that our "highly urbanized country has chosen to have powerless cities, and that this choice has largely been made through legal doctrine."18 Frug further noted another paradoxical development: "[n]ot only are cities unable to exercise general governmental

governments, and the federal government, to enact policies and programs to meet or beat Kyoto Protocol targets suggested for the U.S.; and urge the U.S. Congress to establish a national emission trading system); CITY OF N.Y., PLANYC: A GREENER, GREATER NEW YORK (2007), http://home2.nyc.gov/html/planyc2030/downloads/pdf/full_report.pdf (containing, in part, New York City's plan to reduce global warming emissions by more than $30 \%$ ); TOronto Energy Efficiency Office, Climate Change, Clean Air and Sustainable En. ERGY ACTION Plan: MOVING from Framework to ACTION, Phase 1 (2007), http://www.toronto.ca/changeisintheair/pdf/clean_air_action_plan.pdf (containing Toronto's reduction targets for greenhouse gases from the 1990 levels of $6 \%$ by $2012,30 \%$ by 2020 , and $80 \%$ by 2050); see also Matthew Garrahan, Antonio Villaraigosa: Mayor Sets Agenda for the Nation, FIN. TIMES, Oct. 27, 2008, http://www.ft.com/cms/s/0/906430ac-a3b5lldd-942c-000077b07658.html?nclick_check=1 (documenting the desire of Los Angeles Mayor Villaraigosa to make L.A. "the greenest city in the nation"). Developing countries are also beginning to articulate climate change responses, as is the case, for example, with Mexico City. See Programa de Acción Climática de la Ciudad de México 2008-2012 (2008) (copy on file with author). In addition, although a national rather than local initiative, the Indian Prime Minister's Council on Climate Change, National action Plan on Climate Change: Government of India, http://pmindia.nic.in/Pg01-52.pdf (last visited Oct. 15, 2008) merits attention for its focus on urban effects of climate change and policies appropriate to address them.

17. See, e.g., Bureau of Nat'l Affairs, Climate Change: House Energy Chairman Releases Draft Bill That Would Preempt State Climate Actions, DAILY ENV'T REP., Oct. 8, 2008, at A-11; Bureau of Nat'l Affairs, Outlook for Capping U.S. Emissions in 2009 May Hinge on Depth of Economic Upheaval, DAILY ENV'T REP., Oct. 2, 2008, at B-3; Arnold Schwarzenegger \& Jodi Rell, Op-Ed., Lead or Step Aside, EPA: States Can't Wait on Global Warming, WASH. POST, May 21, 2007, at A13 (criticizing the EPA's refusal to allow twelve states to enact tougher tailpipe emissions standards). Despite congressional efforts to the contrary, however, federal regulators have begun to show signs of accepting local government efforts as a productive route of climate change action. See Bureau of Nat'l Affairs, EPA Regions Using Existing Programs to Help Industry, Governments Cut Emissions, DAILY ENV'T REP., Sept. 8, 2008, at A-1.

18. Gerald E. Frug, The City as a Legal Concept, 93 HaRv. L. Rev. 1059, 1059-60 (1980). 
power, but they also cannot exercise the economic power of private corporations." 19

In the context of global climate change debates, Frug's observation is instructive: in climate change, corporate interests are among those recognized as having a stake in resolving the problem, while cities are not. The corporate interest is often included because it is modified by the adjective "multinational," as if the mere fact of doing cross-boundary business merits inclusion with governmental stakeholders. At the same time, corporate interests are also included because they are "sectoral." That is, they represent manufacturers, industries, and features of modern life that have helped create the problem. Yet, as was the case when Frug wrote about the legal place of U.S. cities, in global climate change cities are not recognized as meriting similar influence and a seat at the table. This is true despite their being home to the majority of the world's population.

Frug's analysis of this private/public divide, and its privileging of private interests, helps illuminate the relative exclusion today-in a different context and nearly thirty years later - of city voices in climate change debates. That is, the exclusion of cities from a central place at the table in climate change discussions may be said to occur because of a fundamental distrust of them. As Frug noted of U.S. cities:

there is a widespread belief that although cities are supposed to protect the public interest, they cannot really be trusted to do so. This distrust engenders support for state and federal control of cities to prevent local abuse of power, curb local selfishness, or correct the inefficiencies resulting from "balkanized" local decisionmaking. City discretion of any kind evokes images of corruption, patronage, and even foolishness. This sense of necessity and desirability has made local powerlessness part of our definition of modern society, so that decentralization of power appears to be a nostalgic memory of an era gone forever or a dream of romantics who fail to understand the world as it really is. ${ }^{20}$

Many of these arguments, albeit in softer, less caustic form, are typical of the objections to local involvement in global climate change debates, where uniformity and efficiency become the watchwords to guard against a "patchwork" of competing and inconsistent local initiatives. ${ }^{21}$ But Frug's

19. Id. at 1065 .

20. Id. at 1067.

21. J.R. DeShazo \& Jody Freeman, Timing and Form of Federal Regulation: The Case of Climate Change, 155 U. PA. L. REV. 1499, 1521 (2008) (exploring the positive contribution of states in development of federal policy, despite the recognition that " $[t]$ he emerging patchwork of state measures seems perfectly designed to make industry nervous"); see also, e.g., David E. Adelman \& Kirsten H. Engel, Adaptive Federalism: The Case Against Reallocating Environmental Regulatory Authority, 92 MINN. L. REV. 1796 (2008) (defending the 
observations ask us to consider whether this characterization is merited. Indeed, cities might have something useful to bring to the table when solutions to climate change are debated.

The evisceration of municipal power can be seen elsewhere in the world, if for different reasons. For example, Brazil's 1988 constitution theoretically gives equal power to the federal, state, and local governments. However, as lawyer and urban planner Edésio Fernandes has noted, "in Brazil, the decision-making process of urban questions was highly centralized by the federal government, which treated them from a merely technobureaucratic perspective." 22 Fernandes explains that this led to a depoliticization of urban policy and the resulting domination of public patronage and clientele patterns deeply rooted in Brazilian history. ${ }^{23}$ Limited local control and limited participation in decisions affecting land use and environmental management can be noted as well in anglophone Africa:

[I]n many African countries local elected councillors [sic] have little or no say in planning decisions which are controlled by central government. Equally, there is no public participation in the making of plans, or of decisions on development control. The elitist nature of planning law in Nigeria is therefore paralleled throughout anglophone Africa and has been extensively commented on by lawyers. ${ }^{24}$

To be sure, the limitation of the power of cities, and particularly of popular representation within cities, may derive from different root causes. In the United States, Frug argued that cities were disempowered to promote private commercial interests. ${ }^{25}$ In less developed countries, in contrast, this may be done as an imperative of development aid that refuses to wait for the cumbersome process of local decision-making, ${ }^{26}$ while land use decisions in other countries may have been consolidated at the national level in order to secure power of ruling political elites. ${ }^{27}$ Added to this reality, in much of the world, the populations of large areas of cities exist unheard,

use, in environmental regulation of complicated issues such as global warming, of multilayered regulation as "dynamic" and positive); David E. Adelman \& Kirsten H. Engel, Reorienting State Climate Change Policies to Induce Technological Change, 50 ARIz. L. REV. 835 (2008) (arguing that, even in the event of federal climate change regulation, there should be a significant role for the variety of state regulatory programs).

22. Edésio Fernandes, Law and URban Change in BraZIL 43 (1995).

23. $I d$. at 44.

24. Patrick McAuslan, Urbanization, Law and Development: A Record of Research, in Illegal Cities 18, 39 (Edésio Fernandes \& Ann Varley eds., 1998).

25. Frug, supra note 18, at 1101-06.

26. $I d$.

27. Ann Varley, The Political Uses of Illegality: Evidence From Urban Mexico, in ILLEGAL CITIES, supra note 24, at 172, 172-90. 
parallel to, or effectively operating outside of the official legal structure. ${ }^{28}$ Yet elsewhere, customary, heterogeneous land use practices may interfere with the ability of either the government-national, state, or local-or the private market to express itself, so that customary systems co-exist, albeit uncomfortably, with the private market and governmental regulations. ${ }^{29}$ In sum, however, the result is a silencing of local voices.

\section{B. Defining Interests Within Cities}

This begs the question, what "city," exactly, would be given a voice if we were to craft a participatory role for urban populations in the climate change debates? As noted at the outset of this Article, a majority of the world's population now lives in cities, most of them in conditions of distress - from moderate to extreme poverty. ${ }^{30}$ An additional feature of much of this land occupation is that it can be characterized as extra-legal. That is, vast swaths of the slum settlements that constitute the living conditions of the world's majority exist outside of the formal state in which they exist. In practical terms, this can refer to those millions who live in cities without access to municipal services like roads, water, and sewage, ${ }^{31}$ and also for those who live in areas within cities controlled by violent criminal enterprises such that the areas are off-limits to the police, other public safety, and municipal services. ${ }^{32}$ This reality should give pause to those making climate policy at the national and international level; the views of significant portions of the global population may not be given voice at those decision making levels. ${ }^{33}$ Surely good public policy and effective legislation for climate change —or any issue of import-must take into account the

28. See, e.g., Martin Delfin, UN Troops Under Fire in Haitian Slum, EL PAís (Spain), Feb. 14, 2007, at 4 (discussing a gun battle in Port-au-Prince's Soleil slum, which is considered one of Haiti's most dangerous); Jeffrey Gettleman, Chased by Gang Violence, Residents Flee Kenyan Slum, N.Y. TiMES, Nov. 10, 2006, at A4 (discussing gang violence in Mathare, a group of Kenyan slums outside Nairobi, and noting that "[t]he area is notorious as a pocket of anarchy in a relatively orderly city").

29. Alain Durand-Lasserve, Law and Urban Change in Developing Countries: Trends and Issues, in ILLEGAL CITIES, supra note 24, at 233, 235-36 (discussing the distinctiveness of francophone Africa).

30. STATE OF WORLD POPULATION, supra note 5.

31. See, e.g., Winnie V. Mitullah \& Kivutha Kibwana, A Tale of Two Cities: Policy, Law and Illegal Settlements in Kenya, in ILLEGAL CrTIES, supra note 24, at 191, 202-03 (describing characteristics of extra-legal settlements in Nairobi).

32. E.g., Rogelio Pérez Perdomo \& Teolinda Bolívar, Legal Pluralism in Caracas, Venezuela, in ILLEGAL CITIES, supra note 24, at 123, 133.

33. See Edésio Fernandes \& Ann Varley, Law, the City and Citizenship in Developing Countries: An Introduction, in ILlEGAL CITIES, supra note 24, at 3 ("[W]e find that an average of 40 per cent and in some cases as much as 70 per cent of the population of the major cities are living in illegal conditions."); see also supra note 6. 
views of those it seeks to help and whose behavior it will regulate. ${ }^{34}$ At the same time, identifying appropriate representatives of those populations will be no easy task.

Consequently, official, legal governments cannot necessarily be understood to represent urban populations the world over. For many, the rule of law shapes daily life in only the most formal sense. ${ }^{35}$ Therefore, some more pluralist model must be adopted to introduce urban voices-whether characterized as "local," "municipal," or "city" representatives-at the climate change policy roundtable. The fact that so much of the world's population remains effectively disenfranchised from the policy decisions that affect them indicates that all of us must demand a search for a more inclusive governance model, one that applies participatory as well as representative democratic principles to climate change governance. ${ }^{36}$ In short, this is to advocate consideration of a pluralist model to reshape climate change governance.

Legal pluralism recognizes the diversity of existing judicial systems, often within the same society. Although pluralism does not necessarily maintain that all such orders are normatively justified (or justifiable), pluralism does, at a minimum, support a view like the following: I recognize the existence of a non-state legal order and also understand that this order may contradict the moral or political values of the larger political and social order where it is located. ${ }^{37}$ Initially, legal anthropologists and sociologists turned to pluralism to defend the legal and social orders of indigenous and traditional communities. ${ }^{38}$ More recently, legal pluralism has been used to defend the interests of what might be called the "urban disenfranchised"-

34. See Boaventura de Sousa Santos \& Leonardo Avritzer, Introduction: Opening Up the Canon of Democracy, in DEMOCRATIZING DEMOcRaCy: BEYOND THE LIBERAL DEMOCRATIC CANON xxxiv-lxix (Boaventura de Sousa Santos ed., 2005).

35. See, e.g., Perdomo \& Bolivar, supra note 32, at 127 ("[T]he legality/illegality dualism presupposes the existence of an ordered society in which the rule of law prevails and in which both citizens and government acknowledge their responsibility to observe or to ensure the observance of legal norms."); see also Sérgio de Azevedo, Law and the Future of Urban Management in the Third World Metropolis, in ILLEGAL CITIES, supra note 24, at 258, 261 ("In the complex and rapidly changing societies of most developing countries, political participation cannot be limited to traditional institutional channels of representation (the right to elect and to stand for election). It requires other, more direct, forms of democracy for citizenship rights to be fully realized, especially at the local level. In short, the management of public affairs is too important to be left to the government.").

36. de Sousa Santos \& Avritzer, supra note 34, at lxvi (insisting on "new complementarities" between participatory and representative democracy).

37. See, e.g., John Griffiths, What is Legal Pluralism?, 24 J. Legal PluRalism 1 (1986); Sally Engle Merry, Legal Pluralism, 22 LAW \& SOC'Y REV. 869 (1998).

38. See Merry, supra note 37 , at 875-79. 
that is, the urban poor of so many of the world's largest cities. ${ }^{39}$ Interestingly, some research suggests that the legal orders observed and implemented in such communities often mirror the practices of the larger society (for example, in establishing land title and developing systems to mediate land conflicts). ${ }^{40}$ A pluralist framework offers a mechanism to identify concurrent legal or social orders within nation-states.

In the climate change context, a pluralist model would permit urban interests to be identified and brought to climate change discussion. A powerful advantage of using such a model would be to help refocus the climate change debate away from the "developed" versus "developing" country distinction. ${ }^{41}$ Such an effort would incorporate into climate change analysis and discussion not only questions of inequality between states but also inequality within states, comparing the behaviors of those who do not have and consume little within given countries against those who have and consume in those same countries. This will likely have the effect of demonstrating how the "haves" in the developing countries benefit from this inequality, revealing their role in producing climate change, while also identifying similar interests among the global poor, whether in "developed" or "developing" countries, including the heightened risks that the global poor face from climate change, a fact that has been extensively documented. ${ }^{42}$ A likely consequence of thus redefining the appropriate parties in climate change discussions would be to deepen our understanding of the challenges of successful climate policy change in the mega-urban centers where most people now live, and where they are projected to continue to concentrate.

Such an approach may be justified on several grounds. First and most obviously, it would satisfy the commitment to equitable solutions articulated in the Framework Convention on Climate Change. ${ }^{43}$ More concretely, it could reinforce another central objective of the Framework Convention: namely the desire to reduce both anthropogenic carbon emissions

39. See generally Daniel Bonilla Maldonado, Extralegal Property, Legal Monism, and Pluralism, U. MIAMI INTER-AM. L. REV. (forthcoming 2009) (unpublished draft manuscript on file with author).

40. See id.

41. See, e.g., Doran \& Ginnochio, supra note 16, at 35-41.

42. Id. at $50 \mathrm{n} .88$.

43. United Nations Framework Convention on Climate Change art. 3(1)-(3), May 9, 1992, 1771 U.N.T.S. 107, available at $\mathrm{http} / /$ unfccc.int/resource/docs/convkp/conveng.pdf [hereinafter UNFCC]. Article 3(1) articulates a commitment equity to "protect the climate system". Article 3(3) creates a duty of "taking into account different socio-economic contexts" and to "comprise all economic sectors" in defining policies and measures to address climate change. 
and poverty. ${ }^{44}$ The voices of unrepresented parties in climate change governance can presumably speak more eloquently to what is needed to improve their quality of life, while also implementing strategies to reduce the effects of global warming than can their official representatives.

In addition, there are positive social utilities to incorporating a voice for cities at the table of climate change governance. First, there are significant spillover effects from the limited regulation of slums and shantytowns; the better-to-do cannot insulate themselves from the violence and other social and environmental ills produced by their less well-off neighbors. ${ }^{45}$ Indeed, it appears that when the better-to-do try to insulate themselves, by, for example, choosing "to meet their housing needs in enclosed condominium developments connected to the central areas via motorways, light rail or metro systems," 46 their actions serve only to increase urban sprawl and its negative consequences for climate change, such as an increase in impermeable surfaces and vehicle miles traveled. ${ }^{47}$ Bringing disenfranchised representatives of urban populations to the table in climate change negotiations might promote workable solutions that take account of the lives led by many of the world's urban residents. On climate-related issues such as

44. The Preamble to the UNFCC affirms, among other things, "that responses to climate change should be coordinated with social and economic development in an integrated manner with a view to avoiding adverse impacts on the latter, taking into account the legitimate priority needs of developing countries for the achievement of sustained economic growth and the eradication of poverty ...." See also id. art. 4(7).

45. For example, in Brazil, the World Bank and the Inter-American Development Bank, in cooperation with other investors, engaged in remediation problems for important water resources in São Paulo and Rio de Janeiro, the country's two largest cities. Both the River Tietê, in São Paulo, and the Bay of Guanabara, in Rio de Janeiro, had been seriously polluted by unregulated industrial and sewage discharges-the latter largely coming from the shantytowns, or favelas, that surround the cities. See SERGIO MARGULIS ET AL., BRAZIL: MANAGING WATER Quality, MAINSTREAMING THE ENVIRONMENT IN THE WATER SEctor 19-48 (2002), available at http://www-wds.worldbank.org/servlet/WDSContentServer/WD SP/IB/2003/03/15/000094946_03030404241233/Rendered/PDF/multi0page.pdf; see also

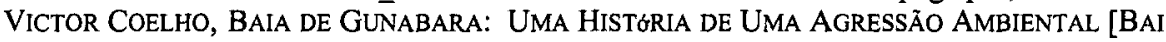
DE Gunabara: A History OF ENVIRONMENTAL AGGRession] 214-22 (2007) (concluding that the poor urbanization surrounding the Bay contributes to its continuing degradation and development plans for the communities need to be implemented gradually but deliberately, and only then will environmental quality improve).

46. Azevedo, supra note 35, at 261-62.

47. Michael M. Maya, Note, Transportation Planning and the Prevention of Urban Sprawl, 83 N.Y.U. L. REV. 879, 884 (2008) (discussing the costs of urban sprawl which include a considerable increase in the average distance suburbanites traveled between home and work since the beginning of the 1980s); Patrick Moulding, Note, Fare or Unfair? The Importance of Mass Transit for America's Poor, 12 GEO. J. ON POVERTY L. \& POL'Y 155, 168-69 (2005) (noting that highway construction not only has negative environmental consequences on the poor but also disproportionately impacts their neighborhoods). 
transportation and spatial planning, ${ }^{48}$ the solutions might surprise us if generated by a base that includes urban populations.

This assumes that the interests and perspectives of governments and their representatives, like those of the carbon-producing industries within their borders, may diverge from those of the world's urban poor. ${ }^{49}$ This further assumes that, in the long-term, solutions will not be workable unless developed and supported by all sectors of national populations. In fact, the "search for broader economic and political solutions" is often impeded by mistrust or lack of familiarity between the urban poor, and the social and economic actors responsible for the operation of the formal state and economy. ${ }^{50}$

Incorporating such urban voices in climate change governance can lead to more efficient solutions. Including a wider range of urban voices in the process of formulating climate change policy may force serious discussion, for example, about densification in planning (and how to achieve it), rather than continued toleration of the climate-negative effects of urban sprawl. This would be possible because the broader model of participation envisaged here would result in a vigorous discussion among all social and economic actors. A collateral benefit of broader participation is that it would highlight internal differences within societies that could only help sharpen the tools with which climate change is addressed. ${ }^{51}$ For example, in international negotiations, China and India have been among the loudest "developing" nation voices insisting that "developed" nations should not be allowed to inhibit their carbon emissions until they reached a comparable stage of development, even as their carbon emissions soared. ${ }^{52}$ However,

48. See UNFCC, supra note 43 , art. $4(1)$ (c) (mentioning transportation planning requirements); see also Kyoto Protocol to the United Nations Framework Convention on Climate Change art. 10(b)(i), Dec. 10, 1997, 37 I.L.M. 22 [hereinafter Kyoto Protocol] (creating transportation and spatial planning commitments).

49. See supra notes $36-37$ and accompanying text.

50. Azevedo, supra note 35 , at 262 . Azevedo acknowledges that because of urban violence, the tendency of the middle class is to physically isolate themselves from the poor, and that:

the middle class reaction is an understandable response to the rise in urban crime and violence. However, the habit of regarding the 'other' (from a lower social group) as a potential enemy tends to reinforce ideological prejudices in the elite, undermining the search for broader economic and political solutions such as a reduction in the amount of absolute poverty.... Id.

51. See supra notes 41-42 and accompanying text.

52. See, e.g., Deborah E. Cooper, The Kyoto Protocol and China: Global Warming's Sleeping Giant, 11 GEO. INT'L ENVTL. L. REV. 401, 407-08 (1999) (discussing the "fundamental rift" in the approach to climate change between developed and developing countries). For information regarding current emissions figures see Neth. Envtl. Assessment 
such emissions come at a cost, typically for the most politically, socially and economically disenfranchised members of those societies. ${ }^{53}$ At the same time, the elites in those societies typically demonstrate the most carbon-consumptive behaviors of their brethren in "developed" societies. Conversely, as the proliferation of climate change policies from U.S. cities reflects, there are significant constituencies in some localities concerned to reduce their carbon footprint. ${ }^{54}$ Inserting local voices into climate change negotiations would likely make these internal differences more evident. Thus, it would be possible to craft responses that recognize the behaviors and needs of entire populations rather than narrow segments of individual societies.

At present, however, such a discussion is difficult. The structure of climate change discussions effectively blocks local voices.

\section{Consequences of NOT HeARING FRom Cities in Climate Change Debate}

In much U.S. legal scholarship and policy analysis of climate change, climate change conflicts tend to be addressed as matters that can be resolved along one of three axes: among nations (multi-lateral discussions among global legal institutions), between two nations (bilateral), and between a national government and its states or other administrative units (intra-national). In addition, because many, if not most, analysts tend to view climate change as an economic problem that can be addressed in part by the law and not as an environmental problem with economic and social causes that can be addressed in part with legal solutions, much U.S. writing tends to reject the most popular proposals to address climate change as politically impractical, unpalatable, and/or unfair to the United States. ${ }^{55}$ Even when analysts avow an interest in resolving the seriousness of climate change,

Agency, China Now No. 1 in $\mathrm{CO}_{2}$ Emissions; USA in Second Position, July 24, 2008, http:// www.mnp.nl/en/dossiers/Climatechange/moreinfo/Chinanownol inCO2emissionsUSAinsec ondposition.html (noting that in 2006 China surpassed the United States as the largest emitter of carbon dioxide). See also Emma Graham-Harrison \& Chris Buckley, China says Greenhouse Gases Catch up with U.S., REUTERS NEws, Oct. 29, 2008, http://www.reuters. com/article/naturalResources/idUSPEK12708120081029 (quoting a Chinese official who stated "our total [greenhouse gas] emissions are about the same as the United States").

53. Intergovernmental Panel on Climate Change, Climate Change 2007: SynTHESIS REPORT 65 (2007), available at http://www.ipcc.ch/pdf/assessment-report/ar4/syr/ar4 syr.pdf ("There are sharp differences across regions and those in the weakest economic position are often the most vulnerable to climate change and are frequently the most susceptible to climate-related damages, especially when they face multiple stresses.").

54. See supra note 16.

55. See David M. Driesen, Sustainable Development and Market Liberalism's Shotgun Wedding: Emissions Trading Under the Kyoto Protocol, 83 IND. L.J. 21 (2008). 
the cross-national and economic focus tends to result in conclusions that have the effect of tolerating the status quo, rather than pressing for a reconsideration of its basic features.

A recent article by Eric Posner and Cass Sunstein helps to illustrate the point. ${ }^{56}$ Their analysis of the deficits of cross-national efforts to resolve climate change is fairly typical in two respects: (a) its conclusion that most such solutions are deeply unfair to some national actors, notably the United States; ${ }^{57}$ and (b) in its assumption that the most promising solutions for climate change are economic in nature, specifically either a cap-and-trade system or a carbon tax. ${ }^{58}$ Although they assert that it is not their intention "to sketch a positive approach to climate change," 59 the net consequence of their analysis serves to inhibit any efforts to resolve climate change problems bilaterally or multilaterally. Posner and Sunstein do appear to believe that the United States has erred in not entering into global climate change commitments. ${ }^{60}$ In fact, they believe that some mixture of welfarist or other policies probably should be adopted with respect to climate change. ${ }^{61}$ Nonetheless, their analysis of the principal justifications, and notably the distributive and corrective justice defenses, for climate change policy, by failing to push for workable solutions to climate change, could also well have the result of encouraging continued inaction.

Posner and Sunstein begin by likening the threat of climate change to that of an asteroid hitting the earth:

[A]ssume that all nations are threatened by [an] asteroid .... But the risk is not identical. Because of its adaptive capacity, its location, its technology, and a range of other factors, assume that the United States is less vulnerable to serious damage than (for example) India and the nations of Africa and Europe. ${ }^{62}$

From this example ${ }^{63}$ of an asteroid hit, Posner and Sunstein continue to suggest that distributional or corrective justice justifications for climate

56. Eric A. Posner \& Cass R. Sunstein, Climate Change Justice, 96 GEO. L.J. 1565 (2008)

57. Id. at 1568 .

58. Id. at 1574-75; see also Kyoto Protocol, supra note 48, art. 17 (outlining a framework for emissions trading).

59. Posner \& Sunstein, supra note 56, at 1612.

60. See id. at 1568-69.

61. Id. at 1570 .

62. Id. at 1584 .

63. The example is laden, one might note, with unexplained assumptions that might be said to reveal a nationalistic hubris. Why is our adaptive capacity necessarily greater than that of nations that are the lineal descendents of civilizations dating back centuries if not millennia? What if our technology fails us? 
change action are, at best, "highly imperfect" cause they do not appeal to any compelling national interest) at worst. ${ }^{65}$

The distributional justice argument, in basic outline, goes something like this: because climate change is a global problem with disproportionate effects on poorer regions of the world, it behooves the world's richer nations (which also happen to be some of the more heavily-polluting) to invest more in solving the problem. ${ }^{66}$ Posner and Sunstein reject this because, they argue, "[i]t is not at all clear that [redistribution] should take the particular form of a deal in which the United States joins an agreement that is not in its interest." ${ }^{167}$ They further maintain that distributional justice to address climate change, either by way of income transfer by rich nations to poor nations or heavy emission reductions limits of richer countries, simply does not make (economic) sense: "purely as an instrument of redistribution, emissions reductions on the part of the United States are quite crude." 68 Why? Because, they continue, "there is a highly imperfect connection between distributive goals on the one hand and requiring wealthy countries to pay for emissions reductions on the other." ${ }^{69}$ Thus, they quite simply are not convinced that a compelling justification can be identified for the application of distributive justice principles to combating climate change on a global scale. They acknowledge as follows:

[I]t is quite possible that $100 \mathrm{X}$ is better spent on malaria nets and AIDS drugs than on global emissions control, if the only goal is to help the poor. To be sure, it may be that, in fact, the best way to spend $X$ is to cut greenhouse gas emissions. It is possible, for example, that more lives are saved from cutting greenhouse gas emissions than from distributing malaria nets and AIDS drugs, given a constant amount of money and taking into account that future lives and current lives must be put on a common metric. We cannot exclude this possibility, but we can say that the match between greenhouse gas reductions and distributive justice is quite crude. ${ }^{70}$

Posner and Sunstein further buttress their arguments with counterarguments, only to shoot them down in short order. They continue to explain, for example, that choosing to cut greenhouse emissions instead of giving direct aid "might be counted as a virtue because the governments of

64. See Posner \& Sunstein, supra note 56, at 1611 (speaking specifically of corrective justice).

65. Id. at 1612 .

66. See id. at 1570.

67. Id. at 1584 .

68. Id. at 1587.

69. Id.

70. Id. at 1588 . 
many poor states are either inefficient or corrupt (or both)," many programs transferring aid from developed to developing nations have failed to succeed. By this logic, cutting greenhouse emissions-likely by means of cap-and-trade programs or a carbon tax-would be preferred to any other form of aid. Yet, once again, for various reasons, including the uncertain future payoff of present action and the possibility of corruption in the distribution of carbon-reduction permits, the moral appeal of distributive justifications for climate policy are suspect for them. ${ }^{72}$ The tautological character of these arguments merit attention: foreign aid (nation to nation) tends - they say-to fall into the wrong hands, and, even though aid to help address some of the health side effects of climate and environmental change merits our compassion, moral sentiment should not guide us because it will just be diverted by corruption. ${ }^{73}$ Therefore, Posner and Sunstein's analysis implies, we should take our hearts off our sleeves, forget poverty reduction and pursue (it is suggested, if not stated) those solutions to global problems like climate change in our national (and perhaps common) economic interest. Quietly and efficiently, their analysis thus pushes redistributive claims to the side. Therefore, in short, distributive justice proves for them intellectually flabby -at least as a justification for multilateral resolution of climate change problems.

Corrective justice arguments are similarly unavailing for Posner and Sunstein. As they explain, "[c]orrective justice arguments are backwardlooking, focused on wrongful behavior that occurred in the past." 74 This is the argument typically advanced by countries with developing economies undergoing spectacular industrial growth, like China and India: despite their new status as heavy greenhouse gas emitters, the nations first to industrialize, they say, bear more responsibility now because of their historical contribution to the problem. Although they acknowledge that the corrective justice problem is "lamentably complex," Posner and Sunstein maintain that:

"The most general point, summarizing the argument as a whole, is that the climate change problem poorly fits the corrective justice model, because the consequence of tort-like thinking would be to force many people who have not acted wrongfully to provide a remedy to many people who have not been victimized." 75

71. Id. at 1589.

72. See id. at 1590 .

73. $I d$.

74. Id. at 1592 .

75. Id. It should be noted, moreover, that there are areas of tort law in which we accept that corrective justice principles are inadequate to compensate directly for all harms, but al- 
That is to say, for example, that an environmentally conscious North American, who lives in a small apartment, takes the bus or rides her bike to work, and generally adopts behaviors designed to reduce her carbon footprint should not be required to shift assets (in the form of taxes that would then be transferred as financial assistance from the United States) to a country like India, where a newly rich titan of industry, living in an enormous mansion and getting around in fancy, gas-guzzling imported sports cars, is significantly contributing to the problem, at least as judged individually. Thus, application of corrective justice principles is for Posner and Sunstein a dead end:

The basic problem for corrective justice is that dead wrongdoers cannot be punished or held responsible for their behavior, or forced to compensate those they have harmed. At first glance, holding Americans today responsible for the activities of their ancestors is not fair or reasonable on corrective justice grounds, because current Americans are not the relevant wrongdoers; they are not responsible for the harm. ${ }^{76}$

This makes it difficult, if not impossible, for them to endorse corrective justice as a justification for climate change policy and response: such justifications rely heavily upon "notions of collective responsibility that are not easy to defend." 77 Certainly if one analyzes climate change problems as matters for state resolution by use of corrective justice to effect economic redistribution at an international scale, this may be true.

Posner and Sunstein maintain that their goal "has been to clarify the uses and limits" of distributional and corrective justice arguments, "in a way that might bear not only on climate change, but also on a wide range of other questions raised when some nations make claims on others." 78 Yet despite this recognition, they remain open to the criticism that they have boxed themselves in by their nation-centric perspective. Because their units of analysis are the nations at the table of climate change discussions, they are not forced to grapple with the mosaic of climate change effects en-

low compensation nonetheless. A notable example is market share liability. See, e.g., RESTATEMENT (THIRD) OF TORTS: Liab. PhYSICAL HARM $\S 28 \mathrm{cmt}$ o (Tentative Draft No. 5, 2007); RESTATEMENT (THIRD) OF TORTS: APPORTIONMENT LIAB. $\S 26 \mathrm{cmt}$. n (2000); RESTATEMENT (SECOND) OF TORTS $\S 876(\mathrm{~b})$, (c) (1979). In the environmental context, an example is joint and several strict liability for a wide range of actors, including those who did not actually cause the harm. See Comprehensive Environmental Response, Compensation and Liability Act of 1980,42 U.S.C. $\$ 9607$ (a)(1) (2002). Of course, these examples do not mirror the situation described by Posner and Sunstein, whereby some who did not harm are compensating some who have not been harmed.

76. Posner \& Sunstein, supra note 56, at 1593.

77. Id. at 1602 . As noted above, tort law deals, if imperfectly, with compensation for collective harms all the time.

78. Id. at 1612 . 
dured by people and places who happen to live on one side or another of a national boundary. ${ }^{79}$

It should be emphasized that Posner and Sunstein, and many others like them, are not foes of climate regulation, or at least not of policies that may increase quality of life and standard of living, making adaptation to climate change more broadly possible. ${ }^{80}$ Nonetheless, their argument figuratively rejects a search for inclusive climate change solutions and is nation-centric in its examination of the problem. It assumes that the poor within the borders of each state are represented by and cared for by their respective governments. Yet, in a world evermore characterized by income inequality within nations, ${ }^{81}$ this is arguably not a correct, much less a useful or informative way to analyze such redistributive or corrective justice possibilities. The elite in São Paulo, Mexico City, or Mumbai, for example, are likely to have far more in common with the elite in Washington, D.C., London, or Frankfurt, just as the most economically and socially disadvantaged members of each of those places has more in common with their counterparts

79. It should be stressed that this criticism relies upon the conclusion that the limitations of their argument are typical rather than unique. Richard Stewart and Jonathan Wiener, for example, similarly favor entry of the United States into multilateral climate agreements yet note, with some sympathy, the reasons U.S. interests object to doing so. See Stewart \& Wiener, supra note 3, at 51-52 (observing that "the advantages and disadvantages of joining the Kyoto Protocol 'as is' appear to us to be fairly closely balanced").

80. See Posner \& Sunstein, supra note 56 , at $1584-85$. The authors note that:

If resources should be redistributed from rich to poor on the ground that redistribution would increase overall welfare or promote fairness, the intuition appears sound. But there is an immediate problem: If redistribution from rich nations to poor nations is generally desirable, it is not at all clear that it should take the particular form of a deal in which the United States joins an agreement that is not in its interest. Other things being equal, the more sensible kind of redistribution would be a cash transfer, so that poor nations can use the money as they see fit. Perhaps India would prefer to spend the money on education, or on AIDS prevention, or on health care generally. If redistribution is what is sought, a generous deal with respect to the threat of an asteroid collision seems a crude way of achieving it.

Id.

81. Media Eghbal, Brazil's New Middle Class Has a Growing Appetite for Consumption, EUROMONITOR INT'L, Sept. 13, 2007, http://www.euromonitor.com/Brazils_new_ middle_class_has_a_growing_appetite_for_consumption (noting that in 2006 the richest $10 \%$ accounted for $46 \%$ of national income, which is slightly higher than a decade ago); David Cay Johnston, Income Gap Is Widening, Data Shows, N.Y. TIMEs, Mar. 29, 2007, at C1 (noting that in the United States, in 2005, the top 10\% of Americans collected $48.5 \%$ of reported income up from roughly $33 \%$ in the late 1970's); Hu Jintao Vows to Reverse Income Disparity, HrNDU, Oct. 16, 2007, http://www.hindu.com/2007/10/16/stories/200710 1654761400.htm (stating that China's richest $10 \%$ hold more than $40 \%$ of the nation's wealth and that regionally the GDP of the wealthiest province is more than ten times that of the poorest province). Income inequality is a growing characteristic of U.S. society as well. See, e.g., Elizabeth Gudrais, Unequal America, HARV. MAG., July-Aug. 2008, at 22. 
elsewhere. This Article suggests that examining the behaviors of these groups in terms of their class and social privilege could help us rethink national debate and evaluate individual and social class behaviors in climate change dialogue. Perhaps by defining shared legal, social, and economic interests across national boundaries, justifications for redistributive or corrective action could be identified that would simultaneously address poverty and the excessive burden that climate change promises to impose on the world's poor.

\section{Refocusing the Climate Change Debate and NoRm ARTICULATION BY CITY VOICES}

Focusing on the behaviors and necessities of the urban poor across the world's cities may help clarify the most appropriate mechanisms to arrest climate change for at least three reasons. First, the slums of major cities concentrate populations and thus common interests and needs. Second, by virtue of this concentration, the urban environments where most people live literally can be hothouses, both in temperature and social condition, that bring into focus the problems that most merit attention. Third, such focus will redirect attention to urban land uses. Land use practices represent the second-largest challenge in addressing climate change, yet are usually understood only in terms of agriculture and forestry uses. ${ }^{82}$ Surely urban land use merits inclusion in this category as well, demanding our attention to the ways in which land is used, and by whom, in the dominant form of human habitation today.

Because the shape of cities is a land use issue, we should give special attention to the mechanisms of growth in the world's cities. Furthermore, as already noted, because many of the world's urban residents are not effectively represented in urban decision making, there is urgency to identify more participatory mechanisms to assure that the voices of more urban residents are incorporated into this process. Before articulating the normative values that including urban voices in climate change governance might generate, however, it is important understand what voices are presently

82. Daniel Bodansky, International Sectoral Agreements in a Post-2012 Climate Framework 12 (May 2007) (unpublished working paper, available at http://www.pewclimate.com/docUploads/International $\% 20$ Sectoral $\% 20$ Aggreements $\% 20$ in $\% 20 \mathrm{a} \% 20$ Post$2012 \% 20$ Climate\%20Framework.pdf) [hereinafter Bodansky, International Sectoral] (noting that land use is the second highest source of increased anthropogenic carbon emissions). Oddly, however, and following Inter-Governmental Panel on Climate Change and United Nations Framework Convention on Climate Change practice, "land use" is defined as referring to agriculture and forestry only. As understood here, this requires viewing land use in its largest, most comprehensive sense, including urban use of land as well. 
heard and the justifications for listening to them as opposed to more localized voices.

\section{A. Who Is Heard in Climate Change Discussions}

One is hard-pressed to find U.S. climate change analysts who focus on urban groups, especially the poor who constitute the majority of the world's urban population. In addition to global political institutions and national governments, analysts note the roles of "multinational corporate" interests in the definition of new "assumptive frameworks" about energy sources and supplies. ${ }^{83}$ The perspectives of non-governmental organizations also merit consideration. ${ }^{84}$ There is also a pronounced sectoral analysis from those who believe that we should focus first on responses among industrial and economic "sectors" (the manufacturing sector, the transportation sector, and the energy sector), ${ }^{85}$ either in the first instance or as part of an "integrated" strategy that includes bilateral and multilateral responses. ${ }^{86}$ There are also many who argue that state (that is, intra-national) administrative units should have primacy over national (and in the case of the United States, at least, federal) government control. ${ }^{87}$

At the international and national levels, it is argued that for the purpose of uniformity, national actors are better equipped than smaller political and administrative units to prevent the proverbial "race to the bottom." 88 Thus, in global climate change matters, the subsidiarity principle, which dictates that the smallest possible administrative unit should be used to resolve problems, is found wanting:

[T] he traditional arguments for decentralization of authority over local drinking water, land use, and the like do not apply with equivalent force. Under the principle of subsidiarity, the global nature of climate change would counsel greater centralization of policy decisions into national, if

83. Doran \& Ginnochio, supra note 16 , at 5.

84. Kal Raustiala \& Natalie L. Bridgeman, Nonstate Actors In The Global Climate Regime (UCLA Sch. of Law Pub. Law \& Legal Theory Research Paper Series, Paper No. 0729, 2007), available at http://ssrn.com/abstract $=1028603$.

85. DeShazo \& Freeman, supra note 21, at 1502.

86. Daniel Bodansky \& Elliot Diringer, Towards an Integrated Multi-Track Climate Framework (Dec. 2007) (unpublished manuscript, available at http://www.pewclimate.org/ docUploads/Multi-Track-Report.pdf). For Bodansky and Diringer, the "bottom-up" approach refers to national proposals advanced for international consideration.

87. See Adler, supra note 3, at 445 n.15 (citing various articles articulating preference for state or local climate control legislation in the United States); Driesen, supra note 14, at 41.

88. Richard L. Revesz, The Race to the Bottom and Federal Environmental Regulation: A Response to Critics, 82 MINN. L. REv. 535 (1997). 
not international, hands, and less authority for state and local governments. 89

A basic problem represented by such conclusions, however, is that neither government and industry, ${ }^{90}$ nor "environmentalists" the interests of most of the world's overwhelmingly poor and increasingly urban population. For this reason, the notion that the subsidiarity principle only allows global responses turns the principle on its head.

Some proposals reflect an attempt to account for inter- and intra-national difference, such as the "integrated multi-track" proposal advocated by the Pew Center on Global Climate Change. ${ }^{92}$ Clearly, there are administrative advantages to such approaches, not least the likelihood of securing reciprocal commitments and uniform, predictable results. ${ }^{93}$

In contrast, concerns proliferate about localized decision-making in the climate change context. Some are familiar from other contexts, such as worries about rent-seeking behavior ${ }^{94}$ and free riders. ${ }^{95}$ Other concerns are based on the global reality of climate change, the magnitude of which requires international agreement. ${ }^{96}$ Once again, however, even with proposals that strive to respect differences in national conditions, ${ }^{97}$ it remains true that much of the world's population is not represented by governments or major social and private corporate institutions. Thus, if we are truly to address global climate change, there must be a mechanism established to include these subordinated voices.

\section{B. Towards New Governance Norms: Some Benefits of Listening to Cities and Shantytowns}

One might ask what cities would have to add to the climate change debate that is not already known. In the course of considering these benefits, however, it is important also to acknowledge the potential practical diffi-

89. Adler, supra note 3, at 447-48 (emphasis added).

90. Bodansky \& Diringer, supra note 86 , at 7-19.

91. DeShazo \& Freeman, supra note 21, at 1541-43 (delineating arguments that would likely be advanced by "environmentalists").

92. Bodansky, International Sectoral, supra note 82.

93. Bodansky \& Diringer, supra note 86 , at 5.

94. See Jonathan H. Adler, Clean Politics, Dirty Profits: Rent-Seeking Behind the Green Curtain, in Political Environmentalism: Going BehIND THE Green 1, 8-9 (Terry L. Anderson ed., 2000) (summarizing examples of regional rent-seeking in environmental law).

95. Adler, supra note 3 , at 448 .

96. Id. at 447-48.

97. See, e.g., Bodansky, International Sectoral, supra note 82. 
culties of giving city or local voices a greater role in the development of climate change law and policy.

\section{Adding Unheard Voices}

Large swaths of the world's cities now exist off the official grid. Often, these areas are effectively off-limits to official authorities. ${ }^{98}$ The result is the growth of cities that can resemble more of a collection of city-states in the medieval mold, where security and services are controlled within the community rather than provided across communities ${ }^{99}$ than the urbansuburban or regional government and cooperative models more familiar to English-speaking North America and Europe. As a result, the people making the policy and enacting the laws that nominally govern an area within a city in fact have little functional authority over it, much less a notion of how life is lived there. This can only have a negative effect on efforts to apply policy (of whatever kind) to such areas. In the context of climate change, this matters because redesigning our urban environments should be a key goal of climate change response.

As noted at the outset of this Article, for instance, many urban environments are increasingly quite violent. ${ }^{100}$ This is hardly surprising, since residents are crammed together with inadequate services, little green space or other recreational areas, few employment opportunities, and, often, poor sanitation. Importantly, these conditions also have consequences for climate change policy. Several examples can be cited that reflect the connection of slum growth and climate change. For example, expanding urban areas, and mostly expansion of unplanned growth by urban migrants, is rapidly eating up precious forests-forests that provide irreplaceable carbon sinks. ${ }^{101}$ This is true in countries as different from one another as Bra-

98. See, e.g., Tranqüilidade e tensão nas fronteiras da cidade partida [Tranquility and tension on the border of the divided city], JORNAL Do BRASIL (Braz.), July 27, 2008, at A20 (noting the absence of the state in the shantytowns of Rio de Janeiro, despite their proximity to prosperous neighborhoods).

99. Davis, supra note 9, at 17 (reporting that "[i]n the Amazon, one of the world's fastest-growing urban frontiers, 80 percent of city growth has been in shantytowns largely unserved by established utilities and municipal transport").

100. See supra note 11 and accompanying text.

101. Intergovernmental Panel on Climate Change, supra note 6; Mary Christina Wood, Law and Climate Change: Government's Atmospheric Trust Responsibility, 38 ENVTL. L. REP. NEwS \& ANALYSIS 10652, 10659 (2008) (maintaining that we should protect remaining carbon sinks that have capacity to cleanse the atmosphere of carbon); Mark Squillace, From "Navigable Waters" to "Constitutional Waters": The Future of Federal Wetlands Regulation, 40 U. MICH. J.L. REFORM 799, 808 (2007) (observing that "wetlands, like forests, provide a substantial carbon sink that can help mitigate the impact of climate change"). 
zil, Colombia, and the Dominican Republic, where rainforests are daily threatened by urban expansion. ${ }^{102}$ Another example to be cited relates to sanitation. The lack of sanitation has implications for climate changerelated issues as varied as sedimentation in water courses and the water quality of coastlines. ${ }^{103}$ However, these problems cannot be solved merely with the imposition of international trading schemes in carbon dioxide or a uniform carbon tax. Specifically, correcting these effects demands an integrated approach that understands urban poverty reduction as a central element in any climate change policy. For example, investments in housing and education might indeed be understood as part of a climate change investment program with both broadly and narrowly focused goals. ${ }^{104}$

This should not be understood as essential merely by appeal to a moral interest, as some commentators contend. ${ }^{105}$ On the contrary, there is an immediate and pressing interest in violence reduction in urban slums for those both inside and outside of the countries where such violence occurs. This is so in the first instance because of spillover social and environmental effects. ${ }^{106}$ For example, the economy of many slums in South America is sustained by drug and, specifically, cocaine traffic, with the demand for those drugs coming principally from Europe and English-speaking North America. ${ }^{107}$ Growing coca plants has consequences for agricultural land

102. Colin Crawford, Protecting Environmentally-Sensitive Areas and Promoting Tourism in "The Back Patio of the United States": Thoughts about Shared Responsibilities in Ecosystem and Biodiversity Protection, 25 UCLA J. ENVTL. L. \& POL'Y 41, 63-81 (20062007); Colin Crawford, The Insistent (and Unrelenting) Challenges of Protecting Biodiversity in Brazil: Finding "The Law That Sticks," 39 U. MIAMI INTER-AM L. ReV. 1, 15-19 (2007); Colin Crawford, Social and Cultural Protection and Environmental Justice: Lessons of the Colombian Model (2008) (unpublished manuscript, on file with author).

103. Zbigniew W. Kundzewicz et al., Freshwater Resources and Their Management, in Climate Change 2007: IMPACts, AdaPTATION, AND Vulnerability. CONTRIBUtion of WORKING GROUP II TO THE FOURTH ASSESSMENT REPORT OF THE INTERGOVERNMENTAL Panel on Climate Change 173, 178-79 (M.L. Parry et al. eds., 2007), available at http://www.ipcc.ch/pdf/assessment-report/ar4/wg2/ar4-wg2-chapter3.pdf (discussing the effects of climate change on water quality in freshwater systems); Robert J. Nicholls et al., Coastal systems and low-lying areas, in ClimATE CHANGE 2007: IMPACTS, ADAPTATION, AND VULNERABILITY. CONTRIBUTION OF WORKING GROUP II TO THE FOURTH ASSESSMENT Report of the Intergovernmental Panel on Climate Change, Supra, at 315, 319, available at http://www.ipcc.ch/pdf/assessment-report/ar4/wg2/ar4-wg2-chapter6.pdf (discussing the effects of increasing human utilization of coastal zones).

104. In contrast to the view of Posner \& Sunstein, for example, who appear to assume that expenditures for education, housing or other social goals are not correlated to climate control. See Posner \& Sunstein, supra note 56, at 1584-85.

105. See, e.g., id. at 1572.

106. Driesen, supra note 55, at 21 (maintaining that various spillover effects are not well accounted for by market liberalism).

107. See, e.g., U.N. OfFICE ON DRUGS AND CRIME, 2008 WORLD DRUG REPORT 70 (2008), available at http://www.unodc.org/documents/wdr/WDR_2008/WDR_2008_eng_web.pdf 
use, and thus for climate policy. ${ }^{108}$ But it also helps to sustain centers of violence, and a culture that creates parallel judicial orders within states and cities. ${ }^{109}$ Such drug-controlled communities largely exist apart from the formal state. ${ }^{110}$

Thus, one needs to ask, how can green space initiatives, new sanitation systems, or efficient transportation systems-all essential elements of a climate change strategy - be introduced in such areas? One way to begin to address this question would be through the application of a judicial pluralist framework that would attempt to do two things. First, it would recognize the existence of such parallel orders as a first step in bringing disenfranchised voices into the climate change debate. Second, it would seek to accommodate the values and needs reflected in such parallel orders within the larger state. This is not, it should be stressed, to argue that a drug lord in control of a shantytown deserves a seat at the table in international climate change negotiations. However, community voices from disenfranchised urban areas need, somehow, to be systematically integrated into climate change discussions.

Far from being based in abstract moral commitments like Posner's and Sunstein's straw men of distributive or corrective justice, the spillover effects could threaten the well-being of the better-off not only in "developing" countries, but in their more prosperous neighbors as well. Suppose, for example, that Brazil's hot; dry summer of 2006 continued for more than one year-along with the violence that characterized that year. This could

(stating that in 2007 the total area under coca cultivation in Bolivia, Colombia, and Peru was 448,743 acres, an area slightly smaller than Delaware); U.N. OFFICE ON DRUGS AND CRIME, WORLD DRUG REPORT 2005: EXECUTIVE SUMMARY 16 (2005), available at http://www.unodc.org/pdf/WDR_2005/volume_1_ex_summary.pdf (noting that in 2003 the value of the global illicit drug market was estimated, in U.S. dollars, at $\$ 13 \mathrm{~B}$ at the production level, \$94B at the wholesale level, and \$322B at the retail level).

108. Cheri-Lynn Wortham, Comment, Methamphetamine and Cocaine Manufacturing Effects On the Environment And Agriculture, 17 SAN JOAQUIN AGRIC. L. REV. 343 (20072008); Coca Trade and Land Use Changes (Am. Univ., Case Studies No. 16, 1997), available at http://www.american.edu/TED/coca.htm; supra note 6 and accompanying text (detailing the global concern with agricultural land use as a climate change source). In a country like Colombia, where the negative agricultural implications of drug crops are widely appreciated, this is a frequent subject of academic commentary. See, e.g., César Ortiz, Agricultura, Cultivos Ilicitos y Médio Ambiente en Colombia, in GUERRA, SOCIEDAD Y MEDIO AMBIENTE 297, 297 (Martha Cárdenas \& Manuel Rodríguez Becerra eds., 2004).

109. See, e.g., Robert Neuwirth, Shadow Cities: A Billion Squatters, A New URBAN WORLD 256-61 (2005); Pérez Perdomo \& Bolívar, supra note 32, at 133. The United Nations Office on Drugs and Crime promotes programs to give "farmers an economically viable, legal alternative to growing coca or opium." See U.N. OfFICE ON DRUGS \& CRIME, UNODC AND ALTERNATIVE DEVELOPMENT, http://www.unodc.org/unodc/en/alternativedevelopment/index.html (last visited Feb. 6, 2009).

110. See supra note 109. 
ultimately disrupt the smooth functioning of Brazilian industry, with reverberations in global manufacturing and financial markets. ${ }^{111}$ It could lead to increased migration-both within nations and across borders, with devastating social and environmental effects. ${ }^{112}$ In short, it is naïve to suppose that only "many millions of poor people would be hurt by the cost of emissions reductions.... [bearing] that cost in the form of higher energy bills, lost jobs, and increased poverty." 113 Poverty may be a problem, as the adage has it, that will always be with us, but to neglect poverty reduction as an essential component of climate change policy would be foolhardy. We can run, but we cannot hide from the disruptions that will result in an ever hotter and more climate-uncertain planet.

\section{Proposals for Infrastructure and Land Reforms: Local Thinking to Aid Global Action}

Another way in which cities would introduce an essential voice in climate change discussions would be with respect to infrastructure planning and land reform. As noted earlier, land use is cited as a major climate change sectoral concern. ${ }^{114}$ However, as already noted, this typically is understood to refer to agricultural land use, and not the intensive urban land use in which most of the world's population is now engaged worldwide. ${ }^{115}$ Cities, however, have much to teach-and much to do-in this respect. For example, urban areas are expanding exponentially, and with them impermeable surfaces that are turning them into heat islands. ${ }^{116}$ Cities are also expanding because of deforestation (a consequence of poor planning

111. See Andrew Downie, Brazil's Slums Face a New Problem: Vigilante Militias; Offduty and Former Police, Prison Guards, and Firefighters Are Moving in to Oust the Drug Gangs, ChristIAN SCI. MONITOR, Feb. 8, 2007 (commenting on the assaults on police stations, banks, supermarkets, and buses in São Paulo in May 2006 that brought the city to a standstill); Larry Rohter, Police Are Criticized in Wave of Gang Violence in Brazil, N.Y. TIMES, May 30, 2006, at A3 (reporting on the violence in São Paulo in early May 2006 that left at least 186 dead and brought the city to a standstill).

112. This potential has already been well-documented. See, e.g., Edésio Fernandes \& Raquel Rolnik, Law and Urban Change in Brazil, in ILlEgal CiTIES, supra note 24, at 140, 140-44 (describing non-participatory urban planning despite high internal urban migration rates throughout twentieth century); see generally MICHAEL T. KLARE, RESOURCE WARS: The NEW LaNDSCAPE OF Global CONFLICT (2001); Gregory S. McCue, Environmental Refugees: Applying International Environmental Law to Involuntary Migration, 6 GEO. INT'L ENVTL. L. REV. 151, 163-65 (1993) (discussing the often negative effects of mass migrations on the local environment).

113. Posner \& Sunstein, supra note 56, at 1587.

114. See supra notes 6-7 and accompanying text.

115. See supra notes 7-8.

116. Howard Frumkin et al., Urban Sprawl and Public Health: Designing, PlanNING, AND BUILDING FOR HEALTHY COMMUNITIES 83-89 (2004). 
and/or uncontrolled development), with the resulting loss of vegetative cover and the carbon heat sinks they constitute. ${ }^{117}$ Moreover, many of the world's largest cities are coastal and so are especially susceptible to the sea level rise accompanying global warming. ${ }^{118}$

However, particularly in the less-developed world, such planning tends to operate in a "depoliticized and technocratic way" that does not involve participation from many of those who will, in theory, be subject to its regulation. ${ }^{119}$ Many areas targeted for land use regulation effectively fall outside the official urban grid and are not effectively controlled by the central state. Future climate change-related spatial planning must take this raality into account. Therefore, any sustained effort to introduce the kind of land use and environmental planning necessary to reduce heat islands and similar phenomena must be reformulated to take account of these areas and the views of their residents.

Examples exist of the ordered resolution of social conflicts within even the poorest slums. Take, for example, the huge satellite city of Bogotá, Colombia known as Jerusalem. Jerusalem "is one of the quarters with the highest number of buildings lacking titles in Ciudad Bolívar."120 Ciudad Bolívar, in turn, is located in the southwest part of the city:

[t]he district counts 658,477 inhabitants, 12,998 hectares [50.2 sq. miles], and 252 quarters. In terms of population it ranks fourth in the city and its inhabitants represent approximately $10 \%$ of the population of [Bogotá] . . .. 95\% of the population lives in poverty conditions ... . [Jerusalem is] one of the poorest, most populated zones with the highest number of problems regarding informality in all of Bogota.. ${ }^{121}$

Nonetheless, a relatively ordered, concurrent system of property title transfer exists within Jerusalem and owners object to any title "regularization" of the land's inhabitants without compensation. ${ }^{122}$

117. Rômulo Silveira da Rocha Sampaio, Seeing the Forest for the Treaties : The Evolving Debates on Forest and Forestry Activities Under the Clean Development Mechanism Ten Years After the Kyoto Protocol, 31 FORDHAM INT'L L.J. 634, 636-38 (2008).

118. Gordon McGranahan et al., The Rising Tide: Assessing the Risks of Climate Change and Human Settlements in Low Elevation Coastal Zones, 19 ENV'T \& URBANIZATION 17, 21 22 (2007), available at http://eau.sagepub.com/cgi/content/abstract/19/1/17 (noting that low elevation coastal zones, defined as land areas contiguous with the coastline up to a ten meter rise elevation, contain $2 \%$ of the world's land and $10 \%$ of its population, or slightly more than 600 million people).

119. See, e.g., Fernandes \& Rolnik, supra note 112, at 140. See generally THE ChaLLENGE OF ENVIRONMENTAL MANAGEMENT IN URBAN AREAS 181-298 (Adrian Atkinson et al. eds., 2000).

120. Bonilla Maldonado, supra note 39 , at $13,16$.

121. Id. at 16-17.

122. Id. at 18 . 
In other countries, the practical problems may differ from this example because extra-legal occupations occur on public and not private land. ${ }^{123}$ That fact does not make their resolution less complicated. Nonetheless, this Article suggests that a judicial pluralist model that would recognize the reality of these extra-legal settlements, and the way in which they have ordered land, would constitute an important first step. Doing so would allow the official state to begin to understand the land use challenges faced by these communities. In the context of climate change governance, this could force a discussion about a truly integrated land use plan, one that would seek to identify solutions that recognize extra-legal development patterns. By giving a voice to the residents of such shantytowns and extra-legal settlements, it will be possible to identify solutions that both take account of and seek to respond to their reality. Ultimately, this could lead to difficult discussions, for example, about achieving density or public spending for efficient transportation options. This argument makes no assumption that incorporating such voices will be simple or produce easy-to-achieve solutions. It suggests, however, that in the areas of climate change regulation involving land and resource use, it is essential to hear from those who stand most to be affected.

Immediate objections to such a proposal likely will focus on the fact that the occupations were extra-legal. "These people," it may be said, "have no right to the land and so do not deserve a place at any table on how to use it." At a municipal or other local level, however, any such objection would be rather like insisting that a slang word not be allowed into a dictionary because it is not "real English." Extra-legal occupations have become a defining aspect of global cities and one that has serious implications for land use and thus climate change. They must be recognized, therefore, as a central challenge to be addressed by any climate change policy. At least with respect to land use planning reform, official governments in less developed countries recognize this by way of programs that seek to "regularize" such

123. For example, in Brazil "occupations" or "invasions" of public land provide constant fodder for public concern. See, e.g., Luis Felipe Reis, Associação Denuncia Desmatamento Irregular: Construções de Luxo Avançam Pela Floresta de Tijuca [Neighborhood Association Denounces Irregular Deforestation: Luxury Constructions Advance Towards the Tijuca National Forest], JoRNAL Do BRAsIL (Braz.), July 5, 2008, at R2; Favelas Derrubam Areas Nobres [Shantytowns Destroy Noble Areas], JorNal Do Brasil (Braz.), March 23, 2008, at R2 (describing how extra-legal occupations have destroyed property values of surrounding legal settlements by as much as $60 \%$ ). See generally LAND RIGHTS \& INNOVATION: IMPROV. ING TENURE SECURTY FOR THE URBAN POOR (Geoffrey Payne ed., 2002) (containing essays on extra-legal occupation and their social, economic, and environmental consequences, on both public and private land, worldwide); McAuslan, supra note 24. 
areas. ${ }^{124}$ However, many such programs do not begin from a pluralist perspective but, instead, seek to impose an external order without considering the circumstances and realities of those living in shantytowns and extralegal settlements. ${ }^{125}$ Therefore, future climate change policy will need to develop new strategies that both recognize and seek to interact with most of the residents of the world's cities. Part IV of this Article offers a framework to begin to do this. First, however, another benefit of giving voice in climate change governance to unheard city voices can be noted.

\section{Focus on Environmental Justice in Climate Change Governance}

Neglecting cities in climate change debates is likely to have the effect of minimizing a deeper understanding of the health consequences of climate change. Specifically, urban areas typically constitute toxic "hot spots," areas where dangerous air and other pollutants are concentrating, with negative effects on their residents. ${ }^{126}$ An often-stated concern about the adoption of the most popular climate change solution, namely a carbon trading system, is that it will intensify the growth of such hot spots. ${ }^{127}$ It seems

124. One such example is the "favela-bairro" (shantytown to neighborhood) program in Rio de Janeiro, funded in part by the Inter-American Development Bank. See InterAmerican Development Bank, Programa de Urbanizacao de Assentamentos Populares do Rio de Janeiro [Urbanization Program for Popular Settlements of Rio de Janeiro] (project summary available at MIT's Urban Upgrading Site, http://web.mit.edu/urbanupgrading/ upgrading/case-examples/ce-BL-fav.html) (last visited Feb. 6, 2009).

125. Education of technocrats and professionals accustomed to the administration of nonparticipatory, top-down plans is difficult but not impossible. One example of a successful challenge to such management was the waste management scheme implemented in Accra, Ghana. See Ben K. Doe \& Doris Tetteh, The Working Group Approach to Environmental Management under the Accra Sustainable Programme, in THE CHALLENGE OF ENVIRONMENTAL MANAGEMENT IN URBAN AREAS, supra note 119, at 171, 178-79.

126. Victor B. Flatt, Gasping for Breath: The Administrative Flaws of Federal Hazardous Air Pollution Regulation and What We Can Learn from the States, 34 ECOLOGY L.Q. 107, 111 (2007).

127. Robert N. Stavins, A U.S. Cap-and-Trade System to Address Global Climate Change 52-53 (KSG Working Paper No. RWP07-052, 2007), available at http://ssm.com/ abstract $=1026353$ (noting this concern in California debates). But see DeShazo \& Freeman, supra note 21 , at $1541-42$. The authors state that:

[greenhouse gas, or] GHG emissions that lead to global warming are different from conventional pollutants. They do not cause harm primarily as a result of local exposures, but because of the stock of GHGs that accumulate in the atmosphere regardless of where the gases are emitted. Nor do they cause interstate spillovers in the traditional sense, by shifting harmful pollutants from one (usually upwind) jurisdiction to another (usually downwind). Unlike acid rain or the pollutants that create smog, it matters not for global warming whether one is a downwind or an upwind state. Rather, global warming is more like the destruction of the ozone layer-it creates externalities on a global scale. 
only logical then, to avoid undesirable secondary effects of climate change that is globally smart and locally dangerous, that those who stand to be most affected by the expansion of hot spots-namely the global urban poor-be included in the delineation of a global climate policy that can be sustained in the long term.

Another popular economic solution to climate change, specifically a carbon use tax, is similarly problematic because it would be regressive. ${ }^{128} \mathrm{By}$ virtue of this basic inequality, it makes sense to include those who stand to be disproportionately burdened by the solution to be involved in its application.

Thus, the inclusion of urban voices advanced in this Article would serve the inclusive, participatory goals of the environmental justice movement. ${ }^{129}$ A related, additional benefit of doing this would be to forestall the possibility of increased violence in the poor areas of our mega-cities. As noted earlier, the relationship between violence and increased temperatures is a phenomenon that has received strong support in empirical research on the subject. ${ }^{130}$ If, along with temperature rise, poor areas also become toxic hotspots and/or suffer regressive carbon taxes that lead to social protest, social and economic chaos is likely to follow.

\section{THE SEARCH FOR A SOLUTION}

Given the complicated, pluralistic reality of the world's mega-cities, the challenge is to define the appropriate urban group or groups to participate in climate change governance. One possible means to do so would be through a deliberate, measured application of a pluralist model that seeks to promote participatory, representative democratic governance. The goal will be to ensure that unheard urban voices are incorporated into climate change policy and response.

Promisingly, commentators have begun to propose models that would permit more nuanced responses to climate change governance that would allow recognition of non-nation state, and even local, actors. Hari Osofsky, for example, argues "the farther one moves from the strict Westphalian model" of international law, namely the notion that international order is based upon consent between "sovereign and equal nation-states," the more possible it becomes to allow for different conceptions, notions that do not

128. Posner \& Sunstein, supra note 56, at 1586 (noting regressive nature of a carbon tax).

129. LuKe W. COle \& Sheila R. Foster, From the Ground UP: EnVironmental Ra. CISM AND THE RISE OF THE ENVIRONMENTAL JUSTICE MOVEMENT 103-21 (2001) (describing some of the promise and pitfalls of different participatory models in environmental justice conflicts).

130. See supra notes 11-12 and accompanying text. 
necessarily "presume[] that the nation-state is impenetrable."131 She and others have examined "bottom-up lawmaking" for climate change action in the context of U.S. cities, whereby "[i]n their day-to-day microdecisions, cities engage with other private and nonprofit actors in an organic lawmaking process whereby practices become norms and norms embed in law."132 Judith Resnik and others have argued for according special status to what they call "translocal organizations of government actors," in order, they maintain, to break the horizontal and vertical thinking that dominates the "federalism grid" in thinking about climate change solutions. ${ }^{133}$ Others argue that applying international relations theory to the behavior of cities can deepen analyses of "cities' motivation and function as attracting capital or serving as neutral 'markets' or 'bankable' locations" and thus their role in shaping a response to climate change. ${ }^{134}$ All of this work has a common dedication to identifying roles for local governments in the shaping of climate change policy. What it lacks, however, is an appreciation that even local governments may not in fact represent the views of many, if not most of their inhabitants.

One opportunity to begin to allow a means to give a meaningful voice to unrepresented urban voices is to structure urban involvement in environmental land management decisions relating to climate change modeled on the successes of participatory budgeting across the world.

The participatory budget:

[I]s an emanation of the theory of participatory democracy, which maintains that citizens must participate directly in political decisions and not merely, as representative democracy would have it, in the choice of political decision makers. It is, therefore, a system of co-governance in which civil society, far from being a haven of survival before an absent or hostile state, is rather a regular and well-organized way of exerting public

131. Hari M. Osofsky, The Georgraphy of Climate Change Litigation Part II: Narratives of Massachusetts v. EPA, 8 CHI. J. INT'L L. 573, 578-579 (2008).

132. Hari M. Osofsky \& Janet Koven Levit, The Scale of Networks? Local Climate Change Coaltions, 8 CHI. J. INT'L L. 409, 413 (2008).

133. Judith Resnik et al., Ratifying Kyoto at the Local Level: Sovereigntism, Federalism, and Translocal Organizations of Government Actors (Togas), 50 ARIZ. L. REV. 709 (2008); see also Parick Parenteau, Lead, Follow, or Get out of the Way: The States Tackle Climate Change with Little Help from Washington, 40 CONN. L. REV. 1453 (2008).

134. Katherine Trisolini \& Jonathan Zasloff, Cities, Land Use, and the Global Commons: Genesis and the Urban Politics of Climate Change 16 (UCLA Sch. of Law, Research Paper No. 08-22, 2008), available at $\mathrm{http}: / / \mathrm{ssrn} . \mathrm{com} / \mathrm{abstract}=1267314$. 
control over the state by means of institutionalized forms of cooperation and conflict. ${ }^{135}$

Declared by the United Nations to be one of the world's forty best urban management programs, ${ }^{136}$ the participatory budget first was conducted in the southern Brazilian city of Porto Alegre in 1989 and has been a staple of that city's operations ever since. Today it is used throughout cities in Latin America, Spain, France, Italy, Canada, and in two widely different Indian states, Kerala and West Bengal. ${ }^{137}$ Although the process is a "very dynamic social and political process," making it difficult "to draw from it many conclusions or projections," the participatory budget "has been a remarkable means of promoting citizen participation in decisions concerning distributive justice, the effectiveness of decisions, and the accountability" of elected political leaders. ${ }^{138}$ In other words, participatory budgeting provides an example of democracy emerging from below and not being imposed from above.

If one considers the possible application of the participatory budget in the context of urban climate change governance along these three axes ${ }^{139}$ alone, it becomes evident that it offers a promising model for a more inclusive form of climate change governance. Before doing so, however, it is useful to briefly describe the evolution of the participatory budget process in Porto Alegre, Brazil where the idea become a reality.

\section{A. The Example of Participatory Budgeting}

To understand the implications and possibilities of a participatory climate change governance model based on the participatory budget model, it is essential to consider the governance traditions against which the idea of the participatory budget reacted as it was originally developed and implemented in southern Brazil. Two principal features of the prevailing modes of Brazilian socio-economic and political life can be observed: an authoritarian political tradition and a deeply unequal society both socially and economically. As de Sousa Santos explains:

Brazil is a society with a long tradition of authoritarian politics. The predominance of an oligarchic, patrimonialist and bureaucratic model of

135. Boaventura de Sousa Santos, Participatory Budgeting in Porto Alegre: Toward a Redistributive Democracy, in DEMOCRATIZING DEMOCRACY, supra note 34, at 307, 307-08 [hereinafter de Sousa, Participatory Budgeting].

136. Id. at 307.

137. See id.

138. Id. at 357.

139. Namely those cited in the previous paragraph-participation concerning distributive justice, effective decisions, and political accountability. 
domination has resulted in a state formation, a political system and culture characterized by the following: political and social marginalization of the popular classes ...; restriction of the public sphere and its privatization by the patrimonialist elites; "artificiality" of the democratic game and the liberal ideology resulting in a huge discrepancy between the "legal country" and the "real country". . . . Brazil is also a society characterized by outrageous social inequalities, which have in fact increased tremendously in the past 20 years .... ${ }^{140}$

As noted in Part I, these authoritarian and unequal traditions lamentably dominate life for millions the world over.

The implementation of the participatory budget in Porto Alegre was no accident. Porto Alegre, Brazil's tenth most-populous city and the capital of the southernmost Brazilian state of Rio Grande do Sul, was an early site of success for the Brazilian Worker's Party, which took power in January 1989 with a commitment to "popular administration."141 In addition, "[1]ike other Brazilian capitals, in the last decades of the twentieth century Porto Alegre experienced an accelerated process of urbanization," with its population doubling between 1960-1980. ${ }^{142}$ Despite the authoritarian and unequal characteristics of Brazilian society, Porto Alegre was especially well positioned for an experiment in participatory politics. Its indices of educational achievement, along with social indicators such as life expectancy and infant mortality, were better than the Brazilian norm. ${ }^{143}$ In addition, "Porto Alegre is a city of ample democratic traditions, a strong, highly organized civil society" and was a source of resistance during the last military dictatorship, from 1964-1984. ${ }^{144}$

The newly elected political leadership focused on the budget when elected to the mayoralty of Porto Alegre, as "[t]he budget is the basic tool of the political contract underlying ... relations [between the state and the citizens] and the interactions of the various state organisms charged with executing such a contract." 145 Importantly, however, as implemented in Porto Alegre, "[t]he participatory budget and its institutional framework

140. de Sousa, Participatory Budgeting, supra note 135, at 308 (internal quotations omitted). U.N. Dev. Programme, Human Development Report 2007/2008, at 282 (2007), available at http://hdr.undp.org/en/media/HDR_20072008_EN_Complete.pdf (indicating that in Brazil in 2004, the share of income or consumption by the poorest $20 \%$ was $2.8 \%$ while the share for the richest $20 \%$ was $61.1 \%$ and that Brazil's Gini index was fifty-seven); see also supra note 81 and accompanying text.

141. de Sousa, Participatory Budgeting, supra note 135 , at 310.

142. Id. at 311 .

143. $I d$.

144. Id.

145. Id at $312-13$. 
have no formal legal recognition."146 This was because, since 1989, the Worker's Party has controlled the Mayor's Office, but not the city's Chamber of Deputies. Legally, the Executive (the mayor) is entitled only to submit the budget to the city legislature, which can be changed or modified as the legislature sees fit.

In political terms, however, because the executive's [budget] proposal is sanctioned by the institutions of the participatory budget and thus by the citizens and community organizations and associations that participate in them, the executive's proposal becomes a fait accompli for the legislative body in view of the political risks for the deputies in voting against the 'will of the citizens and the communities.' 147

In other words, representative democracy bows to the larger, participatory expression of democratic will.

The participatory budget as first implemented in Porto Alegre was based on three principles: (1) all citizens are entitled to participate as citizens, and community organizations have no special standing (in other words, no greater standing than any individual); (2) participation is governed by a combination of direct and democratic governance rules, and internal rules of functioning are decided by participants; and (3) investment priorities and resource allocation follow both "general" and "technical criteria," where "general criteria" are substantive criteria decided by the participatory institutions and "technical criteria" look to questions of technical or economic viability with reference to federal, state or local legal norms. ${ }^{148}$

There are three basic sets of institutions involved in the execution of the participatory budget. First, there are several municipal institutions, the two most important of which are the Planning Office and the Office for Coordinating Relations with Communities. These offices manage the debate with citizens over the participatory budget. ${ }^{149}$ Second, community organizations independent of municipal government, somewhat similar to neighborhood planning associations in the United States, "mediate between citizen participation and the choice of priorities for city regions." 150 The third set of institutions responsible for advancing the participatory budget process are "designed to establish a permanent mediation and interaction between the first two kinds. They are regularly functioning institutions of community participation," notably the Counsel of Participatory Budgeting ("COP" in

146. Id. at 313.

147. Id.

148. Id. at 314 .

149. Id.

150. Id. at 316 . 
its Portuguese acronym). ${ }^{151}$ The COP and a Forum of Delegates are then charged to pursue the "main goal" of the participatory budget, which "is to encourage a dynamics [sic] and establish a sustained mechanism for joint management of public resources through shared decisions on the allocation of budgetary funds and for governmental accountability concerning the effective implementation of such decisions." 152 A thorough description of the highly articulated structure through which the Forum of Delegates and the COP operate is beyond the scope of this Article. In brief, however, it merits explaining only that both entities subsequently work in the sixteen different regions into which the city was divided for execution of the budget. ${ }^{153}$ Within those regions - and sometimes in micro-regions within them, as determined by citizen participants - there are several rounds of plenary assemblies to consider and identify budgeting priorities. ${ }^{154}$ Since 1994, there have been six thematic areas. ${ }^{155}$ For purposes of this paper, the two most notable such thematic areas are Health and Social Welfare and City Organization, Urban, and Environmental Development. ${ }^{156}$ Moreover, these plenaries do not occur without extensive citizens' preparatory meetings, the aim of which "is to collect the demands and claims of individual citizens, grassroots movements, and community institutions, concerning regional or thematic issues; they also initiate community mobilization to select regional delegates." 157

This is not the tidiest of democratic processes, and its structure has evolved over time. For example, there has been regular modification of criteria for delegate selection to the regional forums. ${ }^{158}$ The important thing to note is that the changes were made by broad, participatory choice-to repeat: this is democracy emerging from below, and not imposed from above. In this way, the participatory budget seeks to avoid some of the "deliberative challenges"-and specifically the hijacking of popular desires for established interests-that occurs in some efforts to give voice to grassroots concerns. ${ }^{159}$

The aim, ultimately, is to identify the three budget priorities for which there is consensus. A process of deliberation in the regional councils,

151. Id.

152. $I d$.

153. $I d$.

154. Id.

155. $I d$.

156. Id.

157. Id. at 318.

158. Id. at 319-20.

159. See, e.g., Cole \& Foster, supra note 129, at 115-21. 
which then gets turned back to the COP and other citizen-focused deliberative assemblies, achieves this. There is much back-and-forth throughout the process between citizens, the executive, and the elected representatives. ${ }^{160}$ Throughout, "the executive plays a decisive role." 161 Finally, the expressions of public preference are translated into concrete budget items through a sophisticated system of grading and weighing preferences. This, like so many details of the participatory budget, also changes constantly. ${ }^{162}$

As the above description suggests, participatory budgeting is not a problem-free panacea. Challenges include control over information flows, ${ }^{163}$ concerns about the autonomy of the COP and other citizen-oriented organs; ${ }^{164}$ inadequate representation of women, especially at the higher levels of budgetary decision making; ${ }^{165}$ worries about the entrenchment of the representatives of the popular assemblies; ${ }^{166}$ and tensions in "relations between popular participation and popular representation."167 A recurrent challenge concerns the fact that such a participatory democratic model in a representative system effectively creates "a model of co-government, that is to say, a model for sharing political power by means of a network of democratic institutions geared to reaching decisions by deliberation, consensus, and compromise." 168 This can be unwieldy and requires constant oversight and re-thinking. ${ }^{169}$

Nonetheless, and despite these ongoing struggles, the process appears to have become more robust over time. A remarkable feature of the participatory budget as applied in Porto Alegre (and subsequently copied widely) is that, despite such conflicts and the growing sophistication of the metrics for measuring popular priorities, not to mention an increasingly complex operational structure, the numbers of people involved in the process grew exponentially. ${ }^{170}$ This appears to have been possible only because it:

seeks to articulate measures of participation, on the one hand, with measures of priority and recognized necessity, on the other. The participation measure guarantees the democratic legitimacy of political decisions,

160. See de Sousa, Participatory Budgeting, supra note 135 , at 320-23.

161. Id. at 322 .

162. See, e.g., id. at $324-25$.

163. Id. at $321,345 \& 362$.

164. Id. at 323 .

165. Id. at $337-38$.

166. Id. at $338-39$.

167. Id. at 339 .

168. Id at 343 .

169. $I d$. at $359-66$ (discussing in detail the past problems and future governance challenges with the participatory budget model).

170. Id. at $326-33$ (describing this process). 
whilst the priority and necessity measure guarantees the fidelity, objectivity and transparency of the conversion of political decisions into distributed resources. ${ }^{171}$

The process appears to have engendered strong fidelity to its achievements. Indeed, although some members of the city legislature have advocated legalizing the participatory budget. This has not occurred because its participants value the autonomy made possible by the absence of government regulation of the process. ${ }^{172}$

The participatory principles described above could equally help refine and sharpen the nature of decisions made through the system of climate change governance. As mentioned at the outset of this section, three standard goals of the participatory budget process would equally be served if this model were applied in the context of climate change governance.

\section{B. Promoting Citizen Participation in Distributive Justice Decisions}

This Article has emphasized that much of the world's population is effectively disenfranchised and disconnected from the political and social decision makers who affect their lives. ${ }^{173}$ Moreover, as clever critics of climate change resource allocation discussions have noted, the current justifications for distributive justice in the current climate change governance regime are not compelling. ${ }^{174}$ However, this might not be so if there were a real possibility for citizens to participate in distributive justice decisions. Were people to understand that decisions were being made that will affect how they use land and what environmental resources are available to them, they would likely engage in those decisions and illuminate justifications for resource distribution.

Where we live, and what is available for all of us to stay alive, are of course questions that affect all of us. These are the kinds of questions that would be implicated by participatory climate change governance. Thus, it is likely that many, if not most, people would be animated by the prospect of engagement in such decisions, just as they have been in Porto Alegre and elsewhere by the opportunity to participate in resource allocations affecting the quality of their urban lives. Moreover, this opportunity for citizen participation could help clarify some of the imperfect incentives described by commentators like Posner and Sunstein-described above as the

171. Id. at 335 .

172. $I d$. at 356 .

173. See supra notes $18-34$ and accompanying text. See generally NEUWIRTH, supra note 109.

174. See supra notes 53-75 and accompanying text. 
developed/developing country log-jam of climate change negotiations. Citizen participation in an inclusive process like that achieved in Porto Alegre and elsewhere could provide a solution for some of the more intractable climate change policy issues like the appropriate caps for developed and developing countries. That is, were citizens involved in the process of making decisions currently performed by their elected or self-appointed representatives, the results might be surprising. Citizens of a "developed" country might well, for instance, express a preference for a progressive carbon tax, or vigorous incentives for behaviors that seek to reduce individual and corporate carbon footprints. ${ }^{175}$ Once again, the profusion of local U.S. initiatives seeking to promote aggressive climate change action in the face of federal inaction suggests this might be true. ${ }^{176}$ Similarly, it is conceivable that the urban poor in a "developing" country might express a preference for a more restrained growth trajectory if they could first implement a long-term adaptive management strategy to deal with the projected effects of climate change, or even accept the possibility of less income in the short term in return for a gurantee of cleaner air because of, say, a limit on the number of coal burning utility plants. ${ }^{177}$

\section{Effectiveness of Decisions}

It is equally likely that decisions made with respect to climate change policy would be more effective if they were the product of participatory as well as representative decision-making, assuming effectiveness is judged by the implementation of decisions to change behaviors affecting climate change. As many climate change analysts have noted, claims for compensation, not to mention pleas for resource redistribution, are, to say the least,

175. John C. Dernbach, Harnessing Individual Behavior to Address Climate Change: Options for Congress, 26 VA. ENVTL. L.J. 107, 123-24 (contending that the focus of any effort should be to change behavior and that financial and other incentives can be used to encourage certain behaviors, discourage others, or both); Sewell Chan, Bloomberg Calls for Tax on Carbon Emissions, N.Y. TIMES, Nov. 2, 2007, available at http://cityroom.blogs.nytimes. com/2007/11/02/bloomberg-calls-for-tax-on-carbon-emissions/ (noting that the idea of a carbon tax has been gaining support among not only scholars and environmentalists, but also business groups and the companies that would be directly affected).

176. See supra note 16.

177. See, e.g., World Bank \& State Envtl. Prot. Admin., Cost of Pollution IN China: Economic Estimates of Physical Damages xv (Robert Livernash ed., 2007), available at http://www-wds.worldbank.org/external/default/WDSContentServer/WDSP/lB/ 2007/03/30/000090341_20070330141612/Rendered/PDF/392360CHA0Cost l of 1 Pollution0 1PUBLICl.pdf (stating the surveys conducted as part of the study suggest that people in China value improvements in health beyond productivity gains and are willing to pay to attain these improvements). 
controversial, particularly for interests in developed countries. ${ }^{178}$ The heaviest carbon emitters, and notably the United States, are reluctant to agree to cap-and-trade systems or a progressive carbon tax on the grounds that such mechanisms would be unfairly prejudicial to their interests. ${ }^{179} \mathrm{~A}$ participatory element in climate change governance could help re-direct that resistance inasmuch as it would force us to scrutinize with greater specificity the wide variety of carbon-emitting behaviors (where and by whom) in both developed and developing countries. Thus, urban participation in climate change governance would uncover a much wider range of opinion about and desire to find solutions for climate change than is the case when the stage is occupied only by representative governments in multilateral and bilateral negotiations. ${ }^{180}$

\section{Participatory Democracy and the Accountability of Elected Representatives}

The participatory budgeting model described for use in climate change governance does not, as explained above, replace popular will for representative governance. $^{181}$ On the contrary, as the discussion above outlined, it introduces a participatory voice into representative democracy, producing a new form of co-governance. ${ }^{182}$

The advantages of that model as applied in the budgeting context would apply equally in the context of climate change. That is, for instance, a participatory role for the residents of cities would likely increase the accountability of governments. For instance, imagine that, as a result of the participatory budget process in a number of U.S. cities, the U.S. Conference on Mayors announced its preference for a fixed percentage to reduce cli-

178. See, e.g., Daniel A. Farber, Basic Compensation for Victims of Climate Change, 155 U. PA. L. REV. 1605, 1607 (2007) (noting the fact that any compensation for climate change effects is controversial).

179. See, e.g., Christina K. Harper, Climate Change and Tax Policy, 30 B.C. INT'L \& Comp. L. REv. 411, 419-20 (2007) (noting one reason the United States rejected the Kyoto Protocol is due to the belief that mandatory emissions cuts were a serious threat to the U.S. economy); Stephanie L. Wilson, Dog Days of Climate Change: Heating the Debate for Federal Cap-and-Trade, 28 J. LAND RESOURCES \& ENVTL. L. 163, 170 (2008) (noting that a cap-and-trade policy that mirrored the Kyoto Protocol could cause United States' economic growth to decline and that some economists do not support this model, arguing that it would strain the economy).

180. STEWART \& WIENER, supra note 3, at 41-42 (reporting "differences in circumstances" among developing countries).

181. See de Sousa, Participatory Budgetary, supra note 135, at 360-64 (explaining that the tension between representative and participatory democracy is embedded in the participatory budget process).

182. Id. at $343-52$. 
mate emissions by some number-X\%- $\mathrm{X} \%$ by year $\mathrm{Y}$. Were the official U.S. position on this question to diverge from this stance, surely it would not be sustainable as a political matter, having been endorsed by a broad spectrum of social interests. Suppose similarly that representatives of residents of a group of Indian or Chinese cities were to articulate a comparable position, stating the desire to reduce health care costs for the treatment of respiratory illnesses by limiting the construction of coal-fired utility plants. In this circumstance, it seems equally likely that the popular pressure would alter the official position of the "representative" government.

To be sure, there are many niceties of a participatory model as applied to climate change governance that remain to be worked out. While it worked in Porto Alegre, would it work in cities with lower levels of public education and worse human development indicia? How could it be constructed across cultures and political systems to ensure that the executive power does not steal the decision making powers of the population? What is clear is that in climate change governance, a matter that affects the resolution of one of the greatest social, economic, and environmental threats facing us today, new thinking about the best means to effect climate change policy is essential. As James Gustave Speth, the former administrator of the United Nations Development Program, recently observed:

It is no accident that environmental crisis is gathering as social injustice is deepening and growing inequality is impairing democratic institutions. Each is the result of a system of political economy-today's capitalismthat is profoundly committed to profits and growth and profoundly indifferent to nature and society ... . The best hope for change in America is a fusion of those concerned about the environment, social justice and strong democracy into one powerful progressive force. ${ }^{183}$

Speth might have said that this is the best hope not noly for "America," but also for the globe. As this Article has endeavored to show, the nature and future prospects of the world's mega-cities, without the possibility of a participatory role for their largely unheard residents, will only negatively compound the already severe consequences we face because of anthropogenic climate change. Participatory climate change governance provides one way to create the kind of progressive fusion that we desperately need, in the United States and beyond its borders.

183. James Gustave Speth, Progressive Fusion, Nation, Oct. 6, 2008, at 28; see also Lawrence O. Gostin, Global Health Law Governance, 22 EMORY INT'L L. REV. 35, 37 (2008) (arguing that "[i]f law is to play a constructive role [in improving global health, especially for the poorest nations,] it will require an innovative way of structuring international obligations, and this will in turn require states to accede to a new model"). 